2-12-2019

\title{
The Indirect Effects of Trading Restrictions: Evidence from a Quasi-Natural Experiment
}

\author{
Shujing Wang \\ Tongji University \\ Hongjun Yan \\ DePaul University \\ Ninghua Zhong \\ Tong Ji University \\ Yizhou Tang \\ Tongji University
}

Follow this and additional works at: https://via.library.depaul.edu/buspubs

Part of the Business Commons

\section{Recommended Citation}

Wang, Shujing and Yan, Hongjun and Zhong, Ninghua and Tang, Yizhou, The Indirect Effects of Trading Restrictions: Evidence from a Quasi-Natural Experiment (February 12, 2019). Available at SSRN:

https://ssrn.com/abstract=3333403 or http://dx.doi.org/10.2139/ssrn.3333403

This Article is brought to you for free and open access by the Driehaus College of Business at Digital Commons@DePaul. It has been accepted for inclusion in Publications - Dreihaus College of Business by an authorized administrator of Digital Commons@DePaul. For more information, please contact digitalservices@depaul.edu. 


\title{
The Indirect Effects of Trading Restrictions: Evidence from a Quasi-Natural Experiment ${ }^{*}$
}

\author{
Shujing Wang \\ Department of Economics and Finance \\ School of Economics and Management \\ Tongji University \\ Email: shujingwang@connect.ust.hk
}

\author{
Hongjun Yan \\ Department of Finance \\ DePaul University \\ Email: hongjun.yan@depaul.edu
}

\author{
Ninghua Zhong \\ Department of Economics and Finance \\ School of Economics and Management \\ Tongji University \\ Email: zhongninghua@tongji.edu.cn \\ Yizhou Tang \\ Department of Economics and Finance \\ School of Economics and Management \\ Tongji University \\ Email: yztang@tongji.edu.cn
}

Current version: February 2019

\footnotetext{
${ }^{*}$ We appreciate helpful comments and suggestions from John K.C. Wei and Clark Liu. All remaining errors are our own.
} 


\title{
The Indirect Effects of Trading Restrictions: Evidence from a Quasi-Natural Experiment
}

\begin{abstract}
Stock market trading restrictions directly affect stock prices and liquidity via constraints on investors' transactions. They also have indirect effects by altering the information environment. We isolate these indirect effects by analyzing the effect of stock market restrictions on the corporate bond market. Using the staggered relaxation of the restrictions on margin trading and short selling in the Chinese stock market as a quasi-natural experiment, we find that the relaxation of these restrictions on a firm's stock reduces the credit spread of its corporate bond. This effect is more pronounced for firms with more opaque information or lower credit ratings.
\end{abstract}

Keywords: Trading restrictions, Margin trading, Short selling, Corporate bond spread, Information asymmetry, Quasi-natural experiment, Chinese financial markets

JEL Classification: G12, G15, G18 


\section{Introduction}

The effects of trading restrictions in stock markets have long been a central issue for both academics and policy makers. It is natural to expect stock market trading restrictions to have direct effects on the prices and liquidity in the stock market via constraints on investors' transactions. However, to fully assess the effect of trading restrictions and hence their policy implications, we also need to take into account the indirect effects. For example, the trading restrictions in the stock market may alter the information environment about the underlying firms and hence affect the stock market, as well as other financial markets related to the firms, such as the corporate bond market.

There has been an extensive literature on the direct effect. For example, the removal of selling restrictions leads to lower future stock prices (e.g., Greenwood 2009), the eligibility for margin trading increases stock prices and market liquidity (e.g., Kahraman and Tookes 2017, and Hansman et al. 2018). Our paper, to the best of our knowledge, is the first to analyze this indirect effect, i.e., the effect of stock market trading restrictions on corporate bond prices. Given the large size of the corporate bond market, analyzing this indirect effect is important in and of itself. Moreover, our study also complements the analyses of the effect on the stock market by shedding light on the mechanism of the indirect effects.

We explore a series of quasi-natural experiments in China to examine the causal relation between trading restrictions in the stock market and the credit spreads of corporate bonds. In March 2010, China introduced a pilot program that made a list of stocks eligible for margin trading and short selling. There were four more major additions to this list over time. At the end of our sample (December of 2015), there were nearly nine hundred stocks on this list.

We have two identification strategies to examine the effects of these trading restrictions. The first is based on diff-in-diff tests. Due to the staggered relaxation of the trading restrictions, our analysis does not rely on a single event but a series of events, each of which affects a subset of stocks. This alleviates the concern that an event may coincide with other contemporaneous 
events or change in aggregate variables. The second identification strategy is based on a fuzzy regression discontinuation design (Fuzzy RDD). As discussed in detail in Section 2, stocks were added to the list mostly based on a formula, which is a function of the market capitalization and trading volume. Hence, we can estimate the local treatment effect by contrasting firms around the cutoff points in a Fuzzy RDD. Our main findings are as follows.

First, our diff-in-diff analysis shows that when a stock becomes eligible for margin trading and short selling, the credit spread of its corporate bond decreases by 25 basis points ( $t=4.34)$ in our main specification, which is around $10 \%$ of the average bond spreads. We also conduct a placebo test. For each addition event, we create a fictitious list of 100 stocks that were ranked the highest according to the formula among those that were not added to the list. That is, the stocks on this fictitious list are not eligible for the relaxation of trading restrictions, but are similar to those added to the list according to the ranking formula during the most recent addition. Our placebo test finds no effect on the credit spreads of the firms on this fictitious list.

Second, the evidence based on our alternative identification strategy is similar. By focusing on the firms around the cutoff points, our Fuzzy RDD estimates suggest that when a stock becomes eligible for margin trading and short selling, the credit spread of its corporate bond decreases by 20 to 30 basis points, depending on the choice of the bandwidth.

Third, we find no evidence of anticipation effect in the corporate bond market. As described in detail in Section 2, the selection of stocks for the designated list is largely based on a formula and hence can be mostly predicted. However, we do not find any anticipation effect. The effect on bond spreads is insignificant during the six months before the stocks are added to the list. This effect becomes significant afterwards, and appears to grow over time. Bond yields decrease by 14 basis points ( $t=2.27)$ during the first six months after the removal of trading restrictions in the stock market, and 33 basis points ( $t=3.86)$ afterwards. These results are in contrast to those in the stock market. For example, Hansman et al. (2018) find a strong anticipation effect in the stock market: there is a significant stock price run up in anticipation of the relaxation of trading 
restrictions in the stock market.

Our interpretation of the above findings is that the relaxation of trading restrictions not only increases the trading activities and liquidity in the stock market, it also improves the information environment of the stock market in the sense that the stock prices reveal more of investors' information after trading restrictions are eliminated. Our further evidence appears consistent with this interpretation.

First, when a stock becomes eligible for margin trading and short selling, its price becomes more efficient. Following Hou and Moskowitz (2005), we measure inefficiency as the delay in stock prices: the fraction of individual stock return variation that is explained by lagged market returns. Our diff-in-diff regression shows that when a stock becomes eligible for margin trading and short selling, its price becomes more efficient. Moreover, since the price is now more revealing, there is less informed trading in the stock market. Specifically, we use the probability of informed trading (PIN) measure in Easley et al (1996) and the price impact measure in Huang and Stoll (1996) to measure the degree of informed trading. Our evidence suggests that the degree of information asymmetry about a stock decreases after the trading restrictions on the stock are relaxed. Similarly, we find that stocks become more liquid after the trading restrictions are alleviated, where liquidity is measured as the bid-ask spread, Amihud (2002) ratio, as well as turover.

Second, the timing of the above effects in the stock market is congruent with the indirect effect in the corporate bond market. In particular, consistent with the timing of the indirect effect on corporate bond yields, we do not find any anticipation effect on our measures of price efficiency and information asymmetry, as well as the bid-ask spread in the stock market. ${ }^{1}$

Third, our interpretation implies that the effects on credit spreads should be stronger for

\footnotetext{
1 Consistent with the findings in Hansman et al (2018), we also find that the trading volume in a stock increases if the stock is expected to be added to the list. Moreover, we find that the Amihud ratio decreases in anticipation of the relaxation of trading restrictions. This is perhaps because that Amihud ratio is constructed based on trading volume.
} 
firms with lower credit ratings. As noted in the literature (e.g., Dang, Gorton, and Holmstrom 2015), the value of a debt contract is insensitive to the information about the firm asset value when the chance of default is remote. Hence, the effect from the information in stock prices should be smaller for firms with higher credit ratings. Indeed, we find that the effect on credit spreads for firms with AA rating or below is around four times stronger than the effect for firms with AAA ratings.

Fourth, our interpretation implies that the effects on credit spreads should be stronger for more opaque firms. Intuitively, all else being equal, investors' belief should respond more to the information in stock prices when the firm is more opaque. We construct a number of proxies for the opaqueness of a firm. The first measure is intangibility. Firms with a high ratio of intangible assets to total assets are considered to be more opaque. The second measure is a dummy variable that indicates whether the stock has dual listed shares (B or $\mathrm{H}$ shares). Cross-listed firms are viewed as more transparent. Our third measure is a dummy variable that indicates whether a firm's financial reports are audited by one of the Big Four auditors in the most recent fiscal year. External auditors play an important role in improving the quality of information contained in financial statements. Firms with high quality auditors are expected to be more transparent. Our fourth and fifth measures are based on analyst forecast errors and dispersions, respectively. Firms with high analyst forecast errors and dispersions are viewed as more opaque. Our findings based on all five measures are consistent with the prediction that the effect on corporate bond yield spreads is stronger for more opaque firms.

Another possible mechanism for the indirect effect is through corporate governance. Margin buying and short selling may improve corporate governance and thus increase bond value. ${ }^{2}$ Using four commonly used corporate governance measures, however, we do not find any evidence that the relaxation of trading restrictions affects corporate governance.

\footnotetext{
${ }^{2}$ Using a regulatory experiment (Regulation SHO) that relaxes short-selling constraints on a random sample of U.S. stocks, Fang, Huang, and Karpoff (2016) show that short-selling curbs earnings management and help detect frauds.
} 
Our paper contributes to the literature on the effects of trading restrictions. For example, Greenwood (2009) shows that when the selling restriction on a stock is lifted, its price tends to drop. Similarly, in the IPO context, a number of studies have documented that stock prices tend to decline on the lockup expiration date though the day of the event is known in advance (Field and Hanka (2001), Bradley, Jordan, and Ritter (2003), Brav and Gompers (2003), and Ofek and Richardson (2003)). Hong, Scheinkman, and Xiong (2006) provide a theoretical analysis. Kahraman and Tookes (2017) find that when a stock becomes eligible for margin trading, its liquidity improves during normal times. Hansman et al. (2018) documents the anticipation effect of the relaxation of trading restrictions. Our study adds to the above literature by analyzing the effects of stock market trading restrictions on the corporate bond market. These effects are necessarily indirect since the trading restrictions apply only to the stock market. We establish a causal relation between the relaxation of trading restrictions in the equity market and the decrease in corporate bond spreads.

Our evidence suggests that information asymmetry is likely to be the main channel through which trading restrictions affect bond spreads. This adds to the literature that documents the effect of information asymmetry on asset prices. For example, Bhattacharya and Daouk (2002) show that information asymmetry increases the cost of equity. Kelly and Ljungqvist (2012) report that stock prices decrease as information asymmetry increases due to the exogenous loss of analyst coverages. Chan, Menkveld, and Yang (2008) find that the China foreign share discount is mainly explained by information asymmetry.

Our paper is related to the studies on margin trading and short selling. There is a large literature that explores the effect of margin trading on asset prices theoretically (e.g., Black (1972), Yuan (2005), Garleanu and Pedersen (2007), Brunnermeier and Pedersen (2009), and Fostel and Geanakoplos (2012)), as well as empirically (e.g., Hardouvelis and Theodossiou, 2002; Bhojraj, Bloomfield and Tayler, 2009; Frazzini and Pedersen, 2014; Kahraman and Tookes, 2017; Jylha 2018). There is also an extensive literature on short selling. A number of 
studies suggest that short sellers are informed and short-sale constraints slow information discovery and decrease price efficiency (Cohen, Diether, and Malloy (2007), Bris, Goetzmann and Zhu (2007), Saffi and Sigurdsson (2011), Beber and Pagano (2013), Boehmer and Wu (2013), Chang, Luo, and Ren (2013), Curtis and Fargher (2014), Fang, Huang and Karpoff (2016), and Engelberg, Reed, and Ringgenberg (2017)). ${ }^{3}$

Finally, and more broadly, our findings are related to the effects of trading restrictions on managerial compensation and corporate governance (e.g., Massa, Zhang, and Zhang (2014), Lin, Liu, and Sun (2018)). Finally, our results also add to the literature that links information asymmetry and credit spreads (e.g., Ivashina, 2009; Han and Zhou, 2014; Derrien, Kecskes, and Mansi, 2016).

\section{Institutional Background and Data Description}

On March 31, 2010, China Securities Regulatory Commission (CSRC) introduced a pilot program, which allows a list of 90 stocks to be bought on margin or sold short. ${ }^{4}$ Since then this designated list has gone through four major revisions, on 12/05/2011, 1/31/2013, 9/16/2013, and 9/22/2014 respectively. Each time, around 200 stocks are added to the list. ${ }^{5}$ Meanwhile, there were also a few minor revisions that affect only a small number of stocks. As of December 2015, the end of our sample period, there were 891 stocks on this list. We obtain the historical data of the designated list from WIND. Table 1 summarizes the detailed information on the revisions of the designated stock list.

According to the Shanghai Stock Exchange (SSE), stocks are selected into the designated

\footnotetext{
3 There is also a large literature that links short-sale constraints to stock overvaluation. See, for example, Miller (1977), Harrison amd Kreps (1978), Chen, Hong, and Stein (2002), Jones and Lamont (2002), Diether, Malloy, and Scherbina (2002), Hong and Stein (2003), Ofek and Richardson (2003), Scheinkman and Xiong (2003), Asquith, Pathak and Ritter (2005), Nagel (2005), and Chang, Cheng and Yu (2007).

4 See http://www.csrc.gov.cn/pub/newsite/zjhxwfb/xwdd/200810/t20081005_68632.html for the announcement, on October 5, 2008, of the initiation of this pilot program.

5 There are also a few minor revisions that only affect a small number of stocks.
} 
list for margin trading and short selling based on a number of minimum requirements, as well as market capitalization and trading volume. ${ }^{6}$ Hence, at each revision, the stocks with the largest market capitalization and highest trading volume are included in the list. Starting from the third revision on January 31, 2013, the selection process has been guided more explicitly by the following rule. First, for each revision, stocks that are not on the list are ranked according to the following measure

$$
X_{\mathrm{i}}=2 \times \frac{\text { Cap }_{\mathrm{i}}}{\text { AveCap }}+\frac{\text { Volume }_{\mathrm{i}}}{\text { AveVolume }},
$$

where $\operatorname{Cap}_{\mathrm{i}}$ is the average tradable market capitalization of stock i, AveCap the average tradable market capitalization across all stocks on the exchange where stock $i$ is listed, $V_{\text {olume }}$ the average trading volume of stock $i$, and AveVolume the average trading volume across all stocks on the exchange where stock $i$ is listed. Second, with some discretion by the exchanges, the top 100 stocks ranked by (1) are added to the list.

Our sample includes all corporate bonds issued by firms listed on the Shanghai and Shenzhen Stock Exchanges with A-shares and traded in the exchanges from January 2009 to

\footnotetext{
${ }^{6}$ See, for example, http://www.sse.com.cn/lawandrules/sserules/trading/universal/c/c_20150906_3976425.shtml, eligible stocks should meet the following minimum requirements:

(1) Stocks have been listed on the exchange for more than 3 months.

(2) For stocks eligible for margin buying, the number of outstanding tradable shares is not less than 100 million shares or the market capitalization of tradable shares is not less than 500 million yuan. For stocks are eligible for short selling, the number of outstanding tradable shares is not less than 200 million shares or the market capitalization of tradable shares is not less than 800 million yuan.

(3) The number of shareholders is not less than 4,000.

(4) One of the following situations did not occur in the last three months:

a) The average daily turnover rate of the stock is lower than $15 \%$ of the daily average turnover rate of the benchmark index, and the average daily trading volume is less than 50 million yuan.

b) The deviation between the average absolute daily return of the stock and the average absolute daily return of the benchmark index exceeds $4 \%$.

c) Stock volatility is more than five times of the volatility of the benchmark index.

(5) The issuing company of the stock has completed the reform of split share structure.

(6) Stock trading is not subject to risk warnings by the stock exchange.
} 
December $2015 .^{7}$ For those firms, we obtain their stock prices, financial statements, corporate governance, institutional holdings, and analyst earnings forecasts from China Stock Market and Accounting Research (CSMAR) database. Corporate bond prices, treasury yields, and detailed information on margin buying/short selling are obtained from WIND. Intraday stock trading data is from RESSET.

As shown in Table 2, our sample includes 16,639 monthly observations of corporate bond spreads, covers 571 bonds issued by 407 companies, among which 239 companies have been included in the designated list during our sample. The credit spread of a corporate bond, denoted as Spread, is the bond yield minus the yield on a Treasury security with comparable maturity. The average bond spread is $2.46 \%$ and the average bond maturity is 3.72 years. For each company, we dine a dummy variable, List, which equals one if the stock is on the designated list (and hence is eligible for margin buying and short selling in the current month) and zero otherwise. The average value of List in our sample is 0.482 , suggesting that $48.2 \%$ of the observations belong to bonds issued by stocks included in the margin trading list.

Probability of informed trading (PIN) is constructed from intraday buy- and sell-initiated orders within a quarter. We use the likelihood function in Easley et al. (1996) and apply the transformation method in Easley, Hvidkjaer, and O’Hara (2010). The average PIN of the sample is 0.110. Price impact $(P I)$ is calculated as the monthly average of daily adverse-selection component of trading costs estimated from intraday data following the method in Levi and Zhang (2015). The average PI of the sample is 2.967 basis points. Price efficiency (PriceEff) is calculated according to Hou and Moskowitz (2005) and Boehmer and Wu (2013). The average price efficiency measure of the sample is 0.289. Detailed definitions of all variables are included Appendix A.

\footnotetext{
7 There are two secondary bond markets in China, the exchange market and the interbank market. Corporate bonds and convertible bonds issued by publicly listed non-financial companies are only traded in the exchange market. Our sample does not include convertible bonds. During 2009-2015, listed companies in China issue 863 billion (in CNY) corporate bonds in total.
} 


\section{Stock Trading Restrictions and Corporate Bond Spreads}

The relaxation of stock trading restrictions allows investors to take on larger positions, and hence directly affects the prices and liquidity in the stock market. For example, Kahraman and Tookes (2017) demonstrates the causal relation between margin trading and improved stock market liquidity during normal times. Hansman et al. (2018) find that in anticipation of the introduction of margin trading on a stock, investors bid up its price to "front run" the investors who are optimistic about the stock, but are capital constrained.

Our focus is the indirect effects. For instance, the higher liquidity in the stock market may improve the price efficiency and reduce the uncertainty about the firms, which then leads to indirect effects on the stock market, as well as other financial markets such as corporate bond market. We will focus on the effects on the corporate bond market in this section, and revisit the effects on the stock market in Section 4.1.

\subsection{The effect on corporate bond spreads}

We estimate the effect of trading restrictions using a difference-in-difference methodology with multiple periods and multiple treatment groups. Specifically, we run the following regression:

$$
\text { Spread }_{i, t}=a_{i}+a_{t}+b_{1} \text { List }_{i, t}+\gamma z_{i, t}+\varepsilon_{i, t},
$$

where Spread $_{i, t}$ is the credit spreads of bond $i$ in month $t$. List $t_{i, t}$ is a dummy variable that equals one if the issuer of bond $i$ is on the designated list in month $t$ and zero otherwise. The coefficient on List ${ }_{i, t}$ captures the effect of the relaxation of trading restrictions on bond spreads. $z_{i, t}$ is a vector of bond and firm characteristics as control variables, including firm size, book-to-market ratio, return-on-assets, leverage, state ownership, bond maturity, bond return

volatility, and bond illiquidity. All accounting variables are measured at the most recent fiscal year end and at least three months are required between the fiscal year end and the current month in order for the accounting information to be released to the market. This regression includes 
bond fixed effects and time fixed effects. The standard errors are clustered at the bond level to account for the presence of serial correlation in the data.

Due to the staggered addition of the list for margin trading and short selling, our identification strategy does not rely on a single event but a series of events, each of which only affects a subset of stocks. This alleviates the concern that a single treatment event may coincide with other contemporaneous events or changes in aggregate variables. Moreover, our control group is not restricted to firms that are never added to the list. In fact, we can estimate equation (2) for firms that are eventually added to the designated list. The regression takes all firms that are not included in the list as the control group, even if they will be included into the list later on.

Columns 1-2 of Table 3 report the regression results based on our full sample. In column 1, the estimated coefficient on List is -0.240 with a $t$-statistic of 4.00 , suggesting that bond spreads decrease by 24 basis points after the firm is included in the list. Given the average spread is 246 basis points, the restriction relaxation leads to a nearly 10\% decrease in credit spreads.

Column 2 controls for various bond and firm characteristics and the coefficient of List remains similar, and is $-0.249(t=4.34)$. It is well documented that bond prices contain a sizable liquidity component. ${ }^{8}$ Hence, we also include various bond (il)liquidity measures as control variables. Our primary measure of bond (il)liquidity, illiquidity_B, is the monthly Amihud (2002) ratio, which is constructed from daily bond return and trading volume. We also construct two other bond (il)liquidity measures from intraday bond trading data: BASpread_B and (In)Depth_B. BASpread_B is the monthly average of intraday bid-ask spread calculated as the ask minus the bid divided by the average bid and ask price. (ln)Depth_B is the natural logarithm of the monthly average of intraday market depth calculated as bid price times bid volume plus ask price times ask volume. Our results remain similar when we use these two alternative liquidity measures as control variables.

\footnotetext{
8 See, for example, Chen, Lesmond, and Wei (2007), Covitz and Downing (2007), Bao, Pan, and Wang (2011), Lin, Wang, and Wu (2011), and Acharya, Amihud, and Bharath (2013).
} 
One concern on the identification strategy is that the selection of stocks to the designated list maybe endogenous. For example, large firms may be more likely to be included in the list. While level differences and common trends are easily handled by the difference-indifference estimator, differential trends among the treatment and control groups will generally lead to inconclusive or erroneous inferences (Roberts and Whited (2013)). To alleviate the concern, we use two alternative samples to test the effect of margin trading.

First, we restrict our sample to firms that are eventually added to the designated list. We essentially use the same set of firms as both the treatment and control group. By excluding firms that are never included in the list, this specification minimizes the systematic differences between the treatment and control groups, and thus alleviates the concern of non-parallel trends. The results based on this sample are reported in columns 3-4. The results remain similar. The coefficient of List is $-0.152(t=2.33)$ and $-0.171(t=2.66)$ for regressions without (column 3$)$ and with (column 4) controls variables, respectively.

Second, we create a matching sample. For each month, each bond issued by a firm on the designated list is matched by a similar bond issued by a firm that is not on the list. The matching is based on the Mahalanobis distance calculated from bond maturity and the issuing firm's stock market capitalization, turnover, and volatility. ${ }^{9}$ The results based on this matched sample, reported in columns 5-6, remain similar. The coefficient on List is $-0.166(\mathrm{t}=2.73)$ and -0.175 $(\mathrm{t}=3.03)$ for regressions without (column 5) and with (column 6) controls variables, respectively.

Figure 1 visualizes the above regression results by plotting the average monthly bond spreads for treated firms, control firms, and the difference between the two groups. The treatment date $(\mathrm{t}=0)$ refers to the month when a stock is included in the designated list. The figure shows that bond spreads of the two groups follow similar trends before the treatment.

\footnotetext{
9 Due to the limited number of bonds available during early sample period, logistic regressions used in propensity-score matching may generate unreliable results. Thus, we use Mahalanobis distance as the matching criteria instead.
} 
Afterwards, however, the treated firms experience significant decrease in their bond spreads. The difference between the average spreads of treated and control firms decreases from - 0.43 percentage point one month before the event to -0.70 percentage point six months after the stocks are added to the margin trading list, which implies a difference-in-difference estimate of 0.27 percentage point.

\subsection{Timing of the effect on bond spreads}

In order to examine the timing of the above effect on bond yields, we replace the dummy variable List $_{i t}$ by three dummy variables: $\operatorname{List}_{i t}(-6), \operatorname{List}_{i t}(6)$, and $\operatorname{List}_{i t}(7+)$. List $_{i t}(-6)$ is one if stock $i$ is not on the list in month $t$ but will be added to the list within 6 months after $t$, and is zero otherwise. Similarly, List ${ }_{i t}(6)$ is one if stock $i$ is on the list in month $t$ and has been added to the list for no more than 6 months, and is zero otherwise. List $_{i t}(7+)$ is one if stock $i$ is on the list in month $t$ and has be added to the list for 7 months or more, and is zero otherwise. Hence, the coefficients of the three new dummy variables reflect the timing of the effects of the relaxation of trading restrictions on credit spreads. The coefficient of $\operatorname{List}_{i t}(-6)$ captures the potential anticipatory effect, the effect on credit spreads during the 6 months before stock $i$ is added to the list. The coefficients of $\operatorname{List}_{i t}(6)$ and List $_{i t}\left(7^{+}\right)$capture the effects during and after the first 6 months, respectively.

Our results, reported in Panel A in Table 4, show that the effect of the relaxation of trading restrictions on credit spreads starts after the firm is included in the list and gets stronger over time. For example, as shown in column 1, the coefficient of $\operatorname{List}_{i t}(-6)$ is $-0.043(t=0.70)$. That is, there is no evidence of anticipatory effect: there is no detectable effect on credit spreads before the trading restrictions are relaxed. In contrast, the coefficients of $\operatorname{List}_{i t}(6)$ and $\operatorname{List}_{i t}\left(\mathrm{~F}^{+}\right)$are $-0.142(t=2.15)$ and $-0.333(t=3.68)$, respectively. That is, the effect on credit spreads is significant after the relaxation of trading restrictions is effective, and gets stronger over time. In the second column, we include bond and firm characteristics as controls, and the results remain 
very similar. These results on the timing of the effect are consistent with the plot in Figure 1.

Our results highlight the difference relative to the effects on the stock market. For example, Hansman et al. (2018) find a strong effect in the stock market before the trading restrictions are actually relaxed. After a stock is added to the list, financially constrained investors would be able to access more credit and are expected to bid up the price of the stock. Anticipating this, unconstrained investors would "front run" and bid up the price of the stock during the several quarters before the relaxation. In contrast, in the corporate bond market, the effect of the relaxation of trading restrictions does not materialize until the restriction is effective, and becomes stronger over time afterwards. In other words, the effect we documented above is not a mere reflection of the effect in the equity market.

\subsection{Placebo tests}

We conduct a placebo test in this section. Specifically, for each of the five major additions to the designated list, we create a fictitious list of stocks that are ranked the highest according to (1) among the stocks that were not added to the list at the addition. That is, after the each addition to the list, the stocks on our fictitious list are not eligible for margin trading or short selling but, according measure in (1), are similar to those became eligible after the most recent revision. We

construct measure (1) based on the data during the three months before each addition event, and choose the number of the stocks on this fictitious list to be the same as the number of stocks that were actually added to the designated list at the most recent revision. Hence, after each major revision, our fictitious list stays the same until the next major revision.

We create a dummy variable List_Placebo $_{\mathrm{it}}$, which is one if stock $i$ is on this fictitious list in month $t$, and zero otherwise. We then rerun regression (2) by adding List_Placebo. The results are reported in Table 5. As shown in column (1) of Panel A, the coefficient of List is -0.275 ( $t=3.83)$. In contrast, the coefficient of List_Placebo is $-0.064(t=1.07)$. That is, the relaxation of the trading restrictions reduces the bond yields of firms on the actual list, but there 
is no such effects on our fictitious list. We include controls in the regression in second column and the results remain very similar.

We decompose the dummy variable List $_{\text {it }}$ into List_New $w_{\text {it }}$ and List_Old it $_{\text {. }}$ List_New it $_{\text {it }}$ is one if stock $i$ is on the actual list in month $t$ and was added to the list in the most recent addition, and zero otherwise. Similarly, List_old ${ }_{\text {it }}$ is one if stock $i$ is on the actual list in month $t$ and has been on the list before the most recent addition, and zero otherwise. That is, List_New includes all the newly added firms while List_old includes firms that have been on the list before that.

We replace List by List_New and List_Old in the regression to account for the timing effect. The results are reported in columns 3-4. In both columns, the coefficients of List_Old and List_New are significantly negative, suggesting that both previously and newly added firms experience lower bond spreads. Moreover, the magnitude of the coefficient of List_New is around half of that of List_Old, consistent with our previous finding that the effect on bond spreads becomes stronger several months after the addition. In contrast, the coefficient of List_Placebo remains insignificant.

Since the selection rule (1) is not explicitly stated until the third addition event (on January 31 2013), we repeat the above placebo analysis in the subsample from February 2013 to December 2015. The results, reported in Panel B, remain very similar to those in the full sample.

In summary, our results suggest that while firms ranked right above the threshold (and thus are included into the list in an addition event) experience lower bond spreads, those ranked right below the threshold (and thus are on our fictitious list) do not experience lower bond spreads.

\subsection{Fuzzy Regression Discontinuity Design}

To further identify the effect of trading restrictions on corporate bond spreads, we analyze it based on a fuzzy regression discontinuity design (Fuzzy RDD) in this section. Note that the measure in (1) is not precise about the exact selection procedure. For example, the exact sample 
period used by the exchanges to construct measure (1) is not publicly known. We use the data during the three-month window before the announcement date of each addition. Hence, our ranking may not be exactly the same as those obtained by the exchanges. Moreover, the exchanges have discretions in their screening rules. Since our measure in (1) cannot completely predict the list for each addition, we adopt the fuzzy RDD to estimate the local treatment effect for this case of local random assignment.

Following Hahn, Todd, and van der Klaauw (2001) and Chang, Hong, and Liskowich (2015), we use two-stage least-squares to estimate the effect of relaxation of trading restrictions. Specifically, we focus on the last three major revisions, since the explicit rule (1) was not adopted until $1 / 31 / 2013$. For revision $k(k=3,4,5)$, and for each stock that is not on the designated list, we compute ranking ${ }_{i}^{k}$ according to measure (1) based on the data during the three months before the revision date. Let $c^{k}$ denote the number of stocks added to the list at revision $k$. The dummy variable $\tau_{i}^{k}$ is one if $\operatorname{ranking}_{i}^{k} \leq c^{k}$, and zero otherwise. Finally, we define the dummy variable $D_{i}^{k}$ is one if stock $i$ is added to the designated list at revision $k$, and zero otherwise.

While $D_{i}^{k}$ is potentially endogenous, $\tau_{i}^{k}$ is locally random around the cutoff and can be

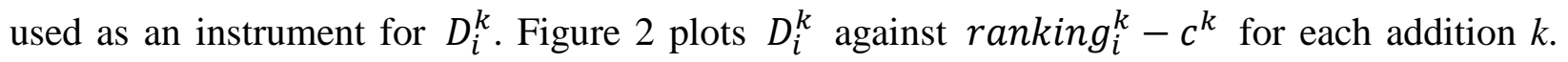
As shown in all three panels, there is a discontinuous jump at the cutoff pint. That is, the probability for a stock to be added to the designated list jump up if its ranking is higher than the cutoff threshold.

We pool the data for all three additions to estimate the first stage regression with a local linear specification:

$$
D_{i}^{k}=\alpha_{0}+\alpha_{1} \tau_{i}^{k}+\alpha_{2}\left(\text { ranking }_{i}^{k}-c^{k}\right)+\alpha_{3} \tau_{i}^{k}\left(\operatorname{ranking}_{i}^{k}-c^{k}\right)+\varepsilon_{i}^{k} .
$$

The estimated coefficient $\alpha_{1}$ represents the discontinuity in the probability of being included in the list at the cutoff. For the second stage, we regress bond spreads after addition $k$ and before the next major revision on $\widehat{D}_{i}^{k}$, which the predicted value of $D_{i}^{k}$ from the first stage. Specifically, 
we pool the data for all three additions to estimate the following regression:

$$
\text { Spread }_{i t}=\beta_{0}+\beta_{1} \widehat{D}_{i}^{k}+\beta_{2}\left(\text { ranking }_{i}^{k}-c^{k}\right)+\beta_{3} \tau_{i}^{k}\left(\operatorname{ranking}_{i}^{k}-c^{k}\right)+v_{i t} .
$$

The estimated coefficient $\beta_{1}$ identifies that local treatment effect on bond spreads. The choice of bandwidth determines the number of firms on each side of the cutoff points in our estimation. In our setup, we vary our bandwidth from 100 to 50 by a step of 10 . Our local linear specification allows the bond spreads to vary linearly on either side of the cutoff. Moreover, we use a triangular kernel in the estimation, which gives more weight on the firms close to the cutoff and thus reduces the potential influence from firms far from the cutoff.

Our estimation results are reported in Table 6. Panel A presents the results from the first-stage regression. In column one, where the bandwidth is 100 , the coefficient $\alpha_{1}$ is 0.591 ( $t=11.76$ ), suggesting that firms just above the cutoff are $59.1 \%$ more likely to be added to the designated list than firms just blow the cutoff. The adjusted $R^{2}$ of the regression is $61.5 \%$. As the bandwidth varies from 100 to 50 , the estimates of coefficient $\alpha_{1}$ remain very similar.

Panel B reports the second-stage regression. In column one, there the bandwidth is 100, the coefficient of interest $\beta_{1}$ is estimated to be $-0.303(\mathrm{t}=3.42)$, suggesting a 30.3 basis point decrease in bond spreads for firms just above the cutoff rank compared with firms just below it. As the bandwidth varies from 100 to 50 , the estimate of coefficient $\beta_{1}$ remains significantly negative. The magnitude of our estimated local treatment effect is only slightly larger than that our baseline regressions in Table 3.

\section{Interpretation}

The above results suggest that there is a causal relation between the stock market trading restrictions and the corporate bond spreads. What is the mechanism through which the relaxation of trading restrictions in the stock market affects bond spreads? Our conjecture is as follows. When margin trading and short selling is allowed, the direct effect is that investors would be able to trade more aggressively in the equity market when needed. As a result, equity prices become 
more informative. The indirect effect is that the more informative equity prices reduce the uncertainty for bond investors and hence increases bond prices (i.e., decrease bond spreads).

To examine this conjecture, we first test if margin trading and short selling reduces the degree of information asymmetry in the equity market and improves its price efficiency in Section 4.1. We then examine the cross-sectional variation in the effect on bond yields in Sections 4.2 and 4.3. Finally, in Section 4.4, we examine an alternative mechanism.

\subsection{The effect in the equity market}

Trading restrictions potentially prevent information from being fully revealed in asset prices, making asset prices noisier and less informative when informed investors cannot fully trade on their signals. Hence, one conjecture is that the relaxation of trading restrictions improves the information environment in the equity market, and enhances the price efficiency and market liquid. To test this conjecture, we run the following regressions

$$
Y_{i, t}=a_{i}+a_{t}+b_{1} L_{i s t_{i, t}}+\gamma z_{i, t}+\varepsilon_{i, t},
$$

where the dependent variable $Y_{i, t}$ is chosen to reflect the market liquidity, price efficiency, and the degree of information asymmetry of stock $i$. Specifically, we adopt the price inefficiency measure Inefficiency from Hou and Moskowitz (2005) and Boehmer and Wu (2013), which is constructed to capture the portion of individual stock return variation that is explained by lagged market returns and essentially is a measure for price delay. We adopt two measures that have been measured to capture the degree of information asymmetry in the stock market, PIN and Cost, where PIN is designed to measure the probability of informed trading (Easley et al. (1996) and Easley, Hvidkjaer, and O’Hara (2010)) and PI is captures the adverse-selection component of trading costs (e.g., Huang and Stoll (1996), Levi and Zhang (2015)). Finally, we adopt three commonly used market liquidity measures, BASpread ${ }_{i, t}$ is the average bid-ask spread of stock $i$ in month $t$, Amihud $_{i, t}$ is the Amihud (2002) illiquidity ratio stock $i$ in month $t$, and Turnover $_{i, t}$ is the logarithm of the average turnover of stock $i$ in month $t$. List $_{i, t}$ is a dummy 
variable that equals one if firm $i$ is on the designated list in month $t$ and zero otherwise. $Z_{i, t}$ is a vector of firm characteristics as control variables, including firm size, book-to-market ratio, return-on-assets, leverage, state ownership, stock return volatility, and stock illiquidity. All accounting variables are lagged for at least three months to make sure that they have been revealed to the market. We restrict our sample to stocks that have valid bond trading data during our sample period. All regressions control for firm and month fixed effects and allow for clustering of the observations at the firm level.

The results are reported in Table 7 . In the first column, where the dependent variable is Inefficiency, in the regression in column six, the coefficient of List is $-0.037(t=4.38)$, suggesting that relaxation of trading restrictions increases the efficiency of stock prices (i.e., reduces the price inefficiency). As shown in column two, where the dependent variable is $P I$, the estimated coefficient of List is $-0.168(t=2.20)$, suggesting that the relaxation of trading restrictions reduces the adverse selection component of trading cost. Similarly, column three suggests that the relaxation of trading restrictions reduces the probability of information trading. These results are consistent with the interpretation that when trading restrictions are removed, it reduces the information asymmetry and improves the price efficiency in the stock market.

In column four, where the dependent variable is the bid-ask spread, the coefficient of List is $-0.014(t=3.43)$, suggesting that the relaxation of trading restrictions reduce the bid-ask spread by 1.4 basis points. Similarly, columns five and six show that the relaxation of trading restrictions reduces the Amihud ratio and increases turnover. Consistent with the findings in Kahraman and Tookes (2017), these results suggest that the relaxation of trading restrictions increases the liquidity in the stock market.

Interestingly, the timing of the above effects in the stock market is congruent with our earlier effects in the corporate bond market. Specifically, as in Section 3.2, we replace the dummy variable List $_{i t}$ by three dummy variables: $\operatorname{List}_{i t}(-6), \operatorname{List}_{i t}(6)$, and $\operatorname{List}_{i t}(7+)$ to examine the timing of the effects on the stock market. As shown in column (1) of Panel B, the 
coefficient of $\operatorname{List}_{i t}(-6)$ is insignificantly different from zero, while those of $\operatorname{List}_{i t}(6)$ and List $_{i t}(7+)$ are highly significant. That is, there appear to be no anticipation effect on market efficiency. The market efficiency of a stock increases only after the trading restrictions on the stock are relaxed. Similarly, columns (2) and (3) show that the effects of trading restrictions on information asymmetry arise only after the restrictions are relaxed. The timing of the effects on bid-ask spreads is similar, as shown in columns (4).

Consistent with the findings in Hansman et al. (2018), as shown in column (6), the trading volume in a stock increases when the stock is expected to be added to the list. Moreover, we find that Amihud ratio decreases in anticipation of the relaxation of trading restrictions. This is perhaps because that Amihud ratio is constructed based on trading volume.

Taken together, our evidence suggests that the anticipation of the relaxation of trading restrictions on a stock increases the trading activities in the stock. However, the market efficiency and information environment of the stock only improves after the restrictions are relaxed. This timing is consistent with our evidence in Section 3 that the information environment of a firm's corporate bond improves only after the trading restrictions on the firm's stock are relaxed.

\subsection{Opaqueness}

In this section, we further test our interpretation that the relaxation of trading restrictions improves the information environment about the underlying firms. An implication from this interpretation is that the improvement should be stronger and so the effect on bond yields should be stronger for more opaque firms.

To test this implication, we adopt a number of measures that are commonly used as proxies for the opaqueness of a firm in the literature. The first measure is intangibility. Firms with high intangible assets to total assets ratios are difficult to value and hence are more opaque (Barth, Kasznik and Mcnichols, 2001; Baylis et al, 2017). We construct a dummy variable, Intangible, 
which is one if the firm's intangible asset ratio is higher than the median of the full sample and zero otherwise. $^{10}$

Our second measure is NoDualList, a dummy variable of cross-listing status that is one if the stock does not have dual listed shares (B or H shares) and zero otherwise. Cross-listed firms commit to higher levels of disclosure and regulations (Bailey, Karolyi and Salva, 2006) and hence investors are able to obtain more precise information about the value of their growth opportunities (Foucault and Gehrig, 2008; Foucault and Frésard, 2012). Thus, dual-listed firms are likely to be more transparent.

Our third measure is NoBig4Audit, a dummy variable that is one if a firm's financial reports are not audited by a Big 4 auditor at the most recent fiscal year end and zero otherwise. External auditors play an important role in improving the quality of information contained in financial statements. Firms with high quality auditors are expected to provide more credible firm-specific information and better investor protection (Gul, Kim and Qiu, 2010). Firms without international Big 4 auditors are likely to be more opaque for outside investors.

We also consider two measures based on analyst earnings forecasts. Analyst forecast errors and dispersions reflect the accuracy of analyst forecasts. Firms with high analyst forecast errors and dispersions are likely to be more opaque (e.g., Thomas, 2002). Error_High is a dummy variable that is one if the firm's analyst forecast error is higher than the median of the full sample and zero otherwise. Dispersion_High is a dummy variable that is one if the firm's analyst forecast dispersion is higher than the median of the full sample and zero otherwise.

We add an interaction term between List and the above five measures to regression (2). The results are reported in Table 8. As shown in column one, the coefficient of the interaction term is -0.135 ( $t=2.00)$, suggesting that the effect on the bond yields of opaque firms is $75 \%$ $(=(0.135+0.179) / 0.179)$ stronger than that on other firms. Similarly, the interaction terms in columns two through five are all highly significant, and their signs are consistent with the

\footnotetext{
10 The results remain similar if we use the intangible asset ratio instead of this dummy variable.
} 
implication that the effect on bond yields is stronger for opaque firms.

Taken together, these results are consistent with the interpretation that the relaxation of trading restrictions improves the information environment for the underlying firms, and hence reduces their bond yields. This effect is stronger when the firm is more opaque.

\subsection{Credit ratings}

As noted in the literature (e.g., Dang, Gorton, and Holmstrom 2015), the value of a debt contract is insensitive to the information on the value of firm asset when the chance of default is remote. Hence the reduction of uncertainty should have smaller effects on bond yields for firms with higher credit ratings.

To test this hypothesis, we augment the regression in (2) by adding interaction terms between List and bond credit ratings. We obtain credit ratings and merge with our earlier sample. Among all 571 bonds in this merged sample, there are 150, 158, 254, and 9 bonds rated as AAA, $\mathrm{AA}+, \mathrm{AA}, \mathrm{AA}-$ at issuance, respectively. We construct a dummy variable $A A A$, which is one if the rating of the firm is AAA, and zero otherwise. Dummy variable AA+ is defined similarly. Due to the small number of bonds with credit rating below AA, we defined a dummy variable AAorBelow, which is one if a bond with current credit rating of AA or below and zero otherwise. We include the three interaction terms, List $\times A A A$, List $\times A A+$, and List $\times A$ AorBelow, in regression (2) and the results are reported in Table 9.

Column 1 presents the estimated coefficients on the three interaction terms between List and credit ratings by controlling for bond, month and credit rating fixed effects. Column 2 further control for various bond and firm characteristics. It is evident that the coefficient on the interaction term is economically and statistically more significant for lower credit ratings. The coefficient on List $\times A A A$ is $-0.065(t=1.02)$, while the coefficients of List $\times A A+$ and List*AAorBelow are $-0.257(\mathrm{t}=3.63)$ and $-0.336(\mathrm{t}=4.36)$, respectively. Our results are consistent with the prediction that the effect from the relaxation of trading restrictions is stronger for firms 
with the lower credit ratings.

\subsection{Corporate governance}

The relaxation of trading restrictions may affect bond yields through the corporate governance channel. As noted in the literature, the relaxation of trading restrictions may improve corporate governance. For example, using a regulatory experiment (Regulation SHO) that relaxes short-selling constraints on a random sample of U.S. stocks, Fang, Huang, and Karpoff (2016) show that short-selling curbs earnings management and help detect fraud. As a result, the removal of reading restrictions would decrease bond yields.

Following Jiang and Kim (2015), we adopt four commonly used corporate governance measures. The first measure is the ratio of independent directors (IndepDir). Firms with low ratio of independent directors are lack of monitoring and have weak corporate governance (e.g., Fama and Jensen, 1983; Weisbach, 1988). The second measure is CEO duality (Dual), which is one if the firm's CEO also serves as the chairman and zero otherwise. Firms with CEO duality is considered to have weak corporate governance. The third measure is the firm's divergence ratio (Divergence), which measures the separation between control rights and ownership rights. As the difference between control rights and cash flow rights increases, controlling shareholders are likely to expropriate firm resources and corporate governance becomes weak (e.g., Shleifer and Vishny, 1997). The fourth measure is managerial ownership (MgtHold), which is defined as the ratio of the total number of shares held by directors, supervisors, and executives to the total number of shares outstanding. The relation between managerial ownership and corporate governance is ambiguous in general. On one hand, managerial ownership may help resolve the agency conflict between insider managers and outside shareholders (Jensen and Meckling, 1976). On the other hand, manager may become entrenched when they own a significant amount of the firm (Fama and Jensen, 1983; Morck, Shleifer, and Vishny, 1988). As discussed by Jiang and Kim (2015), managers in China are rarely get entrenched since the majority of Chinese firms 
have a large controlling shareholder that can easily fire the manager no matter how many shares the manager owns. Thus, firms with low managerial ownership are generally perceived as having high agency costs and weak corporate governance in China.

We regress these measures on List to analyze if the removal of trading restrictions affects corporate governance. As shown in Table 10, in all regressions, the coefficients of List are insignificantly different from zero. That is, we do not find any evidence that this relaxation of trading restrictions affected corporate governance in our sample.

\section{Conclusion}

Trading restrictions directly prevent investors from establishing and adjusting their positions, and hence reduce market liquidity. On the other hand, they also have indirect effects, since they hinder information aggregation. Our paper focuses the indirect effects by analyzing the effects of stock market trading restrictions on corporate bonds. Specifically, we exploit a series of quasi-natural experiments, where around 900 stocks were added, on five occasions, to a designated list, whereby margining trading and short selling became feasible.

Our evidence based on diff-in-diff and fuzzy RDD analysis suggests that this relaxation of trading restrictions in the stock market reduces the yield spread in the corporate bond market. This effect is stronger for firms that are more opaque or have lower credit ratings. Our overall evidence is consistent with the interpretation that the relaxation of trading restrictions improves the information aggregation in the stock market, leading to lower uncertainty about the firm and hence lower bond yields. 


\section{References}

Acharya, Viral V., Yakov Amihud, and Sreedhar T. Bharath. 2013. Liquidity risk of corporate bond returns: Conditional approach. Journal of Financial Economics 110: 358-386.

Amihud, Yakov. 2002. Illiquidity and stock returns: Cross-section and time-series effects. Journal of Financial Markets 5: 31-56.

Asquith, Paul, Parag A. Pathak, and Jay R. Ritter. 2005. Short interest, institutional ownership, and stock returns. Journal of Financial Economics 78: 243-276.

Bailey, Warren, G. Andrew Karolyi, and Carolina Salva. 2006. The economic consequences of increased disclosure: Evidence from international cross-listings. Journal of Financial Economics 81: 175-213.

Bao, Jack, Jun Pan, and Jiang Wang. 2011. The illiquidity of corporate bonds. Journal of Finance 66: 911-946.

Barth, Mary E., Ron Kasznik,. and Maureen F. McNichols. 2001. Analyst coverage and intangible assets. Journal of Accounting Research 39: 1-34.

Bhattacharya, Utpal, and Hazem Daouk, 2002. “The world price of insider trading.” Journal of Finance 57, 75-108.

Baylis, Richard M., Peter Burnap, Mark A. Clatworthy, Mahmoud A. Gad, and Christopher K.M. Pong. 2017. Private lenders' demand for audit. Journal of Accounting and Economics 64: 78-97.

Beber, Alessandro, and Marco Pagano. 2013. Short-selling bans around the world: Evidence from the 2007-09 crisis. Journal of Finance 68: 343-381.

Bhojraj, Sanjeev, Robert J. Bloomfield, and William B. Tayler. 2009. Margin trading, overpricing, and synchronization risk. Review of Financial Studies 22: 2059-2085.

Black, Fischer. 1972. Capital market equilibrium with restricted borrowing. Journal of Business 45: 444-455. 
Boehmer, Ekkehart, and Juan (Julie) Wu. 2013. Short selling and the price discovery process. Review of Financial Studies 26: 287-322.

Bradley, Daniel J., Bradford D. Jordan, and Jay R. Ritter. 2003. The Quiet Period Goes out with a Bang. Journal of Finance 58: 1-36.

Brav, Alon, and Paul A. Gompers. 2003. The Role of Lockups in Initial Public Offerings. Review of Financial Studies 16: 1-29.

Bris, Arturo, William N. Goetzmann, and Ning Zhu. 2007. Efficiency and the bear: Short sales and markets around the world. Journal of Finance 62: 1029-1079.

Brunnermeier, Markus K. and Lasse Heje Pedersen. 2009. Market liquidity and funding liquidity. Review of Financial Studies 22: 2201-2238.

Chang, Eric C., Joseph W. Cheng, and Yinghui Yu. 2007. Short-sales constraints and price discovery: Evidence from the hong kong market. Journal of Finance 62: 2097-2121.

Chang, Eric C., Yan Luo, and Jinjuan Ren. 2013. Cross-listing and pricing efficiency: The informational and anchoring role played by the reference price. Journal of Banking \& Finance 37: 4449-4464.

Chang, Yen-Cheng, Harrison Hong, and Inessa Liskovich. 2015. Regression Discontinuity and the Price Effects of Stock Market Indexing. Review of Financial Studies 28: 212-246.

Chan, Kalok, Albert J. Menkveld, and Zhishu Yang. 2008. Information asymmetry and asset prices: evidence from the china foreign share discount. Journal of Finance 63: 159-196.

Chen, Joseph, Harrison Hong, and Jeremy C. Stein. 2002. Breadth of ownership and stock returns. Journal of Financial Economics 66: 171-205.

Chen, Long, David A. Lesmond, and Jason Wei. 2007. Corporate yield spreads and bond liquidity. Journal of Finance 62: 119-149.

Cohen, Lauren, Karl Diether, and Christopher Malloy, 2007, Supply and Demand Shifts in the Shorting Market, 2007, Journal of Finance, 62, 2061-2096. 
Covitz, Dan, and Chris Downing. 2007. Liquidity or credit risk? The determinants of very short-term corporate yield spreads. Journal of Finance 62: 2303-2328.

Curtis, Asher, and Neil L. Fargher. 2014. Does short selling amplify price declines or align stocks with their fundamental values?. Management Science 60: 2324-2340.

Dang, Tri Vi, Gary Gorton, and Bengt Holmstrom, 2015, Ignorance, Debt and Financial Crises, working paper.

Derrien, François, Ambrus Kecskés, and Sattar A. Mansi. 2016. Information asymmetry, the cost of debt, and credit events: Evidence from quasi-random analyst disappearances. Journal of Corporate Finance 39: 295-311.

Diether , Karl, Christopher Malloy and Anna Scherbina, 2002, Differences of Opinion and the Cross Section of Stock Returns, Journal of Finance, 57, 2113-2141.

Easley, David, and Maureen O'Hara. 2004. Information and the cost of capital. Journal of Finance 59: 1553-1583.

Easley, David, Nicholas M. Kiefer, Maureen O'Hara, and Joseph B. Paperman. 1996. Liquidity, information, and infrequently traded stocks. Journal of Finance 51: 1405-1436.

Easley, David, Soeren Hvidkjaer, and Maureen O'Hara. 2010. Factoring information into returns. Journal of Financial and Quantitative Analysis 45: 293-309.

Engelberg, Joseph E., Adam V. Reed, and Matthew C. Ringgenberg. 2012. How are shorts informed?: short sellers, news, and information processing. Journal of Financial Economics 105: 260-278.

Fama, Eugene F., and Michael C. Jensen. 1983. Separation of ownership and control. Journal of Law \& Economics 26: 301-325.

Fang, Vivian W., Allen H. Huang, and Jonathan M. Karpoff. 2016. Short selling and earnings management: a controlled experiment. Journal of Finance 71: 1251-1294.

Field, Laura Casares, and Gordon Hanka. 2001. The Expiration of IPO Share Lockups. Journal of Finance 56: 471-500. 
Fostel, Ana, and John Geanakoplos. 2012. Why does bad news increase volatility and decrease leverage?. Journal of Economic Theory 147: 501-525.

Foucault, Thierry, and Laurent Frésard. 2012. Cross-listing, investment sensitivity to stock price, and the learning hypothesis. Review of Financial Studies 25: 3305-3350.

Foucault, Thierry, and Thomas Gehrig. 2008. Stock price informativeness, cross-listings, and investment decisions. Journal of Financial Economics 88: 146-168.

Frazzini, Andrea, and Lasse Heje Pedersen. 2014. Betting against beta. Journal of Financial Economics 111: 1-25.

Gârleanu, Nicolae, and Lasse Heje Pedersen. 2007. Liquidity and risk management. American Economic Review 99: 193-197.

Greenwood, Robin. 2009. Trading Restrictions and Stock Prices. Review of Financial Studies 22: 509-539

Grullon, Gustavo, Sébastien Michenaud, and James P.Weston. 2015. The real effects of short-selling constraints. Review of Financial Studies 28: 1737-1767.

Gul, Ferdinand A., Jeong-Bon Kim, and Annie A. Qiu. 2010. Ownership concentration, foreign shareholding, audit quality, and stock price synchronicity: Evidence from China. Journal of Financial Economics 95: 425-442.

Hahn, Jinyong, Petra Todd, and Wilbert Van der Klaauw. 2001. Identification and Estimation of Treatment Effects with a Regression-Discontinuity Design. Econometrica 69: 201-209.

Han, Song, and Xing Zhou. 2014. Informed bond trading, corporate yield spreads, and corporate default prediction. Management Science 60: 675-694.

Hansman, Christopher, Harrison Hong, Wenxi Jiang, Yu-Jane Liu, and Juanjuan Meng, 2018, Riding the Credit Boom, working paper.

Hardouvelis, Gikas A., and Panayiotis Theodossiou. 2002. The asymmetric relation between initial margin requirements and stock market volatility across bull and bear markets. Review of Financial Studies 15: 1525-1559. 
Harrison, J. Michael, and David M. Kreps. 1978. Speculative Investor Behavior in a Stock Market with Heterogeneous Expectations. Quarterly Journal of Economics 92: 323-336.

Hong, Harrison, and Jeremy C. Stein. 2003. Differences of Opinion, Short-Sales Constraints, and Market Crashes. Review of Financial Studies 16: 487-525.

Hong, Harrison, Jose Scheinkman, and Wei Xiong. 2006. Asset Float and Speculative Bubbles, Journal of Finance 61, 1073-1117.

Hou, Kewei, and Tobias J. Moskowitz. 2005. Market frictions, price delay, and the cross-section of expected returns. Review of Financial Studies 18: 981-1020.

Huang, Roger D., and Hans R. Stoll. 1996. Dealer versus auction markets: A paired comparison of execution costs on NASDAQ and the NYSE. Journal of Financial Economics 41: 313-357.

Ivashina, Victoria. 2009. Asymmetric information effects on loan spreads. Journal of Financial Economics 92: 300-319.

Jensen, Michael C., and William H. Meckling. 1976. Theory of the firm: managerial behavior, agency costs and ownership structure. Journal of Financial Economics 3: 305-360.

Jiang, Fuxiu, and Kenneth A. Kim. 2015. Corporate governance in China: A modern perspective. Journal of Corporate Finance 32: 190-216.

Jones, Charles M., and Owen A. Lamont. 2002. Short-sale constraints and stock returns. Journal of Financial Economics 66: 207-239.

Jylha, Petri. 2018. Margin Requirements and the Security Market Line, Journal of Finance 73, 1281-1321, 2018.

Kahraman, Bige, and Heather E. Tookes. 2017. Trader leverage and liquidity. Journal of Finance 72: 1567-1610.

Kelly, Bryan, and Alexander Ljungqvist. 2012. Testing asymmetric-information asset pricing models. Review of Financial Studies 25: 1366-1413.

Levi, Shai, and Xiao-Jun Zhang. 2015. Do temporary increases in information asymmetry affect the cost of equity?. Management Science 61: 354-371. 
Lin, Hai, Junbo Wang, and Chunchi Wu. 2011. Liquidity risk and expected corporate bond returns. Journal of Financial Economics 99: 628-650.

Lin, TC, Qi Liu, and Bo Sun. 2018. Contractual Managerial Incentives with Stock Price Feedback, forthcoming, American Economic Review.

Massa, Massimo, Bohui Zhang, and Hong Zhang. 2014. The Invisible Hand of Short Selling: Does Short Selling Discipline Earnings Management? Review of Financial Studies 28: 1701-1736.

Miller, Edward M. 1977. Risk, Uncertainty, and Divergence of Opinion. Journal of Finance 32: 1151-1168.

Morck, Randall, Andrei Shleifer, and Robert W. Vishny. 1988. Management ownership and market valuation: An empirical analysis. Journal of Financial Economics 20: 293-315.

Nagel, Stefan. 2005. Short sales, institutional investors and the cross-section of stock returns. Journal of Financial Economics 78: 277-309.

Ofek, Eli, and Matthew P. Richardson. 2003. Dotcom Mania: The Rise and Fall of Internet Stock Prices. Journal of Finance 58: 1113-1137.

Roberts, Michael R., and Toni M. Whited. 2013. Endogeneity in empirical corporate finance. Handbook of the Economics of Finance 2: 493-572.

Saffi, Pedro A. C., and Kari Sigurdsson. 2011. Price efficiency and short selling. Review of Financial Studies 24: 821-852.

Shleifer, Andrei, and Robert W. Vishny. 1997. A survey of corporate governance. Journal of Finance 52: 737-783.

Thomas, Shawn. 2002. Firm diversification and asymmetric information: evidence from analysts'forecasts and earnings announcements. Journal of Financial Economics 64: 373-396.

Weisbach, Michael S. 1988. Outside directors and CEO turnover. Journal of Financial Economics 20: 431-460. 
Yuan, Kathy. 2005. Asymmetric price movements and borrowing constraints: A rational expectations equilibrium model of crises, contagion, and confusion. Journal of Finance 60: 379-411. 


\section{Appendix A. Definitions of Variables}

\begin{tabular}{|c|c|}
\hline Variable name & Variable definition \\
\hline Spread (in \%) & $\begin{array}{l}\text { Bond credit spread. The yield of a corporate bond minus the } \\
\text { yield of a Treasury with comparable maturity. Monthly spread is } \\
\text { calculated as the average of daily credit spreads within a month. }\end{array}$ \\
\hline Maturity (in years) & Time to maturity of the bond. \\
\hline Volatility_B & $\begin{array}{l}\text { The monthly bond price volatility is the average of daily bond } \\
\text { price volatility, which is defined as (daily maximum price - daily } \\
\text { minimum price)/daily minimum price. }\end{array}$ \\
\hline Illiquidity_B & $\begin{array}{l}\text { The monthly Amihud ratio of a bond is the monthly average of } \\
\text { daily Amihud ratio for the bond, which is defined as 100×daily } \\
\text { absolute bond return (in \%) divided by trading volume (in } \\
\text { Chinese Yuan). }\end{array}$ \\
\hline BASpread_B (in \%) & $\begin{array}{l}\text { Monthly bid-ask spread of a bond is the monthly average of } \\
\text { intraday bid-ask spread. The bid-ask spread defined as } 2 \times \\
\text { (ask-bid)/(bid+ask). }\end{array}$ \\
\hline (In)Depth_B (in yuan) & $\begin{array}{l}\text { Natural logarithm of the monthly market depth of a bond, which } \\
\text { is the monthly average of intraday market depth. The depth is } \\
\text { defined as bid pricexbid volume + ask pricexask volume. }\end{array}$ \\
\hline List & $\begin{array}{l}\text { A dummy variable, which is one if the stock is eligible for } \\
\text { margin borrowing and short selling in the current month and } \\
\text { zero otherwise. }\end{array}$ \\
\hline (In)Size (in million yuan) & $\begin{array}{l}\text { Natural logarithm of the market capitalization calculated } \\
\text { according to the firm's tradable shares at the month end. }\end{array}$ \\
\hline$B M$ & $\begin{array}{l}\text { Book to market ratio, defined as the book value of equity } \\
\text { divided by the market value of equity at the most recent fiscal } \\
\text { year end. }\end{array}$ \\
\hline$R O A($ in \%) & $\begin{array}{l}\text { Return on Assets, defined as net income divided by total assets } \\
\text { at the most recent fiscal year end. }\end{array}$ \\
\hline Lev & $\begin{array}{l}\text { Leverage ratio, defined as total liabilities divided by total assets } \\
\text { at the most recent fiscal year end. }\end{array}$ \\
\hline SOE & $\begin{array}{l}\text { A dummy variable of state owned enterprise, which equals one } \\
\text { if the firm is state owned in the most recent fiscal year end and } \\
\text { zero otherwise. }\end{array}$ \\
\hline Intangibiity & $\begin{array}{l}\text { Net intangible assets divided by total assets at the most recent } \\
\text { fiscal year end. }\end{array}$ \\
\hline NoDualList & $\begin{array}{l}\text { A dummy variable of cross-listing status, which is one if the } \\
\text { stock is not } A H \text { or } A B \text { cross-listed in the current month and zero }\end{array}$ \\
\hline
\end{tabular}


otherwise

NoBig4Audit

ForecastErr

ForecastDisp

IndepDir

MgtHold

Divergence (in \%)

Dual

PIN

PI (in basis points)

PriceEff
A dummy variable of big four audit, which equals one if the financial report is not audited by a big-four auditing firm at the most recent fiscal year end and zero otherwise

Analyst forecast errors, defined as the absolute difference between the consensus EPS forecast and the actual EPS, scaled by the absolute value of consensus EPS forecast. Consensus EPS forecast is defined as the mean value of EPS forecasted by all analysts on the stock between January 1st and December 31th.

Analyst forecast dispersion, defined as the standard deviation of all analyst EPS forecasts scaled by the absolute value of consensus EPS forecast. Where consensus EPS forecast and dispersion is calculated from the EPS forecasted by all analysts on the stock between January 1st and December 31th.

Numbers of independent directors divided by total numbers of directors at the most recent fiscal year end

Total stock shares held by directors, supervisors and executives divided by total shares outstanding at the most recent fiscal year end

The separation between control rights (voting rights) and ownership rights (cash flow rights) at the most recent fiscal year end, defined as the ultimate controller's control rights minus ownership rights. Control rights are defined as the weakest link in the chain of control rights. Ownership rights are defined as the product of ownership stakes along the chain of control rights.

CEO duality, a dummy variable that equals one if the CEO and chairman is the same person at the most recent fiscal year end and zero otherwise

Probability of informed trading calculated from intraday buyand sell-initiated orders within a quarter. We use the likelihood function in Easley et al. (1996) and apply the transformation method in Easley, Hvidkjaer, and O’Hara (2010).

Price impact, defined as monthly average of daily adverse-selection component of trading costs calculated from intraday data following the method in Levi and Zhang (2015).

Price efficiency is calculated according to Hou and Moskowitz (2005) and Boehmer and Wu (2013). Monthly price efficiency is 
defined as $1-\mathrm{R}_{\text {res }}{ }^{2} / \mathrm{R}^{2}$. Where $\mathrm{R}^{2}$ is $\mathrm{R}$-squared calculated by regressing daily stock return on the same day and four days lagged value-weighted market return. $\mathrm{R}_{\text {res }}{ }^{2}$ is R-squared calculated by regressing daily stock return on value-weighted market return only.

Volatility_S Monthly volatility of the stock, defined as the annualized standard deviation of daily stock returns in the current month

Illiquidity_S Monthly Amihud illiquidity measure of the stock, defined as monthly average of daily stock Amihud ratio. Daily Amihud ratio is defined as $10^{6} *$ daily absolute stock return (in \%) divided by trading volume (in Chinese Yuan) 


\section{Table 1. Additions and Deletions of the Designated List}

This table reports the addition and deletion events on the designated list of stocks that are allowed for margin trading and short selling. Announcement date is the date when the addition or deletion of the designated list is announced. Effective date is the date when the addition or deletion of the designated list takes place. Addition/deletion represents the number of stocks that are added to/deleted from the list. Total represents the number of stocks on the list after the effective. Exchange traded funds (ETFs) are not included in the table.

\begin{tabular}{ccccc}
\hline Announcement Date & Effective Date & Addition & Deletion & Total \\
\hline $2 / 12 / 2010$ & $3 / 31 / 2010$ & 90 & 0 & 90 \\
$11 / 25 / 2011$ & $12 / 5 / 2011$ & 189 & 1 & 278 \\
$1 / 25 / 2013$ & $1 / 31 / 2013$ & 276 & 53 & 501 \\
$9 / 6 / 2013$ & $9 / 16 / 2013$ & 206 & 1 & 700 \\
$9 / 12 / 2014$ & $9 / 22 / 2014$ & 218 & 13 & 900 \\
\hline
\end{tabular}


Table 2. Summary Statistics

This table reports the summary statistics of the monthly data on corporate bonds issued by listed firms with valid bond spreads between January 2009 and December 2015. All accounting variables are measured at the most recent fiscal year end. All continuous variables are winsorized at $1 \%$ and $99 \%$ levels. Definitions of variables are reported in Appendix A.

\begin{tabular}{lcccccccc}
\hline & Mean & StdDev & Min & P25 & P50 & P75 & Max & N \\
\hline Spread & 2.460 & 1.190 & 0.440 & 1.644 & 2.244 & 2.992 & 7.031 & 16,639 \\
Maturity & 3.717 & 1.901 & 0.140 & 2.380 & 3.670 & 4.740 & 9.340 & 16,639 \\
Volatility_B & 0.005 & 0.008 & 0.000 & 0.000 & 0.002 & 0.006 & 0.048 & 16,639 \\
Illiquidity_B & 0.009 & 0.031 & 0.000 & 0.000 & 0.000 & 0.004 & 0.225 & 16,639 \\
List & 0.482 & 0.500 & 0.000 & 0.000 & 0.000 & 1.000 & 1.000 & 16,639 \\
(In)Size & 9.194 & 1.163 & 6.967 & 8.383 & 9.030 & 9.869 & 13.100 & 16,151 \\
BM & 0.701 & 0.396 & 0.120 & 0.416 & 0.627 & 0.907 & 2.113 & 16,570 \\
ROA & 3.481 & 3.507 & -7.209 & 1.304 & 2.894 & 5.400 & 13.715 & 16,605 \\
Lev & 0.574 & 0.150 & 0.197 & 0.475 & 0.584 & 0.686 & 0.846 & 16,605 \\
SOE & 0.586 & 0.493 & 0.000 & 0.000 & 1.000 & 1.000 & 1.000 & 16,598 \\
Intangibiity & 0.051 & 0.078 & 0.000 & 0.012 & 0.031 & 0.061 & 0.538 & 16,605 \\
NoDualList & 0.838 & 0.368 & 0.000 & 1.000 & 1.000 & 1.000 & 1.000 & 16,639 \\
NoBig4Audit & 0.815 & 0.388 & 0.000 & 1.000 & 1.000 & 1.000 & 1.000 & 16,639 \\
ForecastErr & 0.532 & 1.212 & 0.001 & 0.098 & 0.250 & 0.524 & 10.281 & 14,857 \\
ForecastDisp & 0.284 & 0.345 & 0.000 & 0.093 & 0.185 & 0.342 & 2.199 & 14,213 \\
IndepDir & 0.372 & 0.055 & 0.308 & 0.333 & 0.333 & 0.400 & 0.571 & 16,582 \\
MgtHold & 0.050 & 0.130 & 0.000 & 0.000 & 0.000 & 0.004 & 0.608 & 15,981 \\
Divergent & 5.982 & 8.420 & 0.000 & 0.000 & 0.000 & 12.012 & 32.340 & 15,499 \\
Dual & 0.137 & 0.344 & 0.000 & 0.000 & 0.000 & 0.000 & 1.000 & 16,432 \\
PIN & 0.110 & 0.042 & 0.001 & 0.082 & 0.107 & 0.134 & 0.235 & 16,228 \\
PI & 2.967 & 1.469 & 0.213 & 1.940 & 2.744 & 3.765 & 7.822 & 16,116 \\
PriceEff & 0.289 & 0.257 & 0.007 & 0.092 & 0.198 & 0.416 & 0.992 & 16,065 \\
Volatility_S & 0.424 & 0.228 & 0.125 & 0.265 & 0.361 & 0.516 & 1.194 & 16,120 \\
Illiquidity_S & 0.034 & 0.046 & 0.001 & 0.008 & 0.018 & 0.041 & 0.280 & 16,151 \\
\hline
\end{tabular}


Table 3. Trading Restrictions and Corporate Bond Spreads

This table presents the regression of corporate bond spreads on List $t_{i, t}$, which is one if the issuer of bond $i$ is on the designated list in month $t$ and zero otherwise. The full sample includes all bonds with valid spreads during the sample period from January 2009 and December 2015. The List-only sample only includes bonds issued by stocks that have been on the designated list at least once during the sample period. The matched sample includes the list-only sample and its matching sample. For any given month, a bond in the list-only sample is matched to a similar bond issued by stocks that is not on the list. The matching is based on the Mahalanobis distance calculated from bond maturity, stock market capitalization, turnover, and volatility. T-statistics, in parentheses, are based on standard errors clustered at the bond level are reported in parenthesis. *, **, and *** denote statistical significance at the $10 \%, 5 \%$, and $1 \%$ level, respectively.

\begin{tabular}{|c|c|c|c|c|c|c|}
\hline \multirow[b]{2}{*}{ Dep.Var=Spread } & \multicolumn{2}{|c|}{ Full sample } & \multicolumn{2}{|c|}{ List-only sample } & \multicolumn{2}{|c|}{ Matched sample } \\
\hline & $(1)$ & $(2)$ & $(3)$ & $(4)$ & (5) & $(6)$ \\
\hline List & $\begin{array}{c}-0.240 * * * \\
(-4.00)\end{array}$ & $\begin{array}{c}-0.249 * * * \\
(-4.34)\end{array}$ & $\begin{array}{c}-0.152 * * \\
(-2.33)\end{array}$ & $\begin{array}{c}-0.171^{* * *} \\
(-2.66)\end{array}$ & $\begin{array}{c}-0.166 * * * \\
(-2.73)\end{array}$ & $\begin{array}{c}-0.175 * * * \\
(-3.03)\end{array}$ \\
\hline (In)Size & & $\begin{array}{c}-0.076 * \\
(-1.65)\end{array}$ & & $\begin{array}{l}-0.039 \\
(-0.85)\end{array}$ & & $\begin{array}{c}-0.078 * \\
(-1.74)\end{array}$ \\
\hline$B M$ & & $\begin{array}{l}-0.025 \\
(-0.29)\end{array}$ & & $\begin{array}{l}0.040 \\
(0.49)\end{array}$ & & $\begin{array}{r}0.044 \\
(0.58)\end{array}$ \\
\hline$R O A$ & & $\begin{array}{c}-0.057 * * * \\
(-7.34)\end{array}$ & & $\begin{array}{c}-0.039 * * * \\
(-4.12)\end{array}$ & & $\begin{array}{c}-0.056 * * * \\
(-5.53)\end{array}$ \\
\hline Lev & & $\begin{array}{c}0.659 * \\
(1.75)\end{array}$ & & $\begin{array}{l}0.547 \\
(1.52)\end{array}$ & & $\begin{array}{c}1.141^{* * *} \\
(3.11)\end{array}$ \\
\hline$S O E$ & & $\begin{array}{c}0.514 * * \\
(2.40)\end{array}$ & & $\begin{array}{l}0.589 \\
(1.51)\end{array}$ & & $\begin{array}{c}0.337 * \\
(1.79)\end{array}$ \\
\hline Maturity & & $\begin{array}{l}-0.158 \\
(-1.12)\end{array}$ & & $\begin{array}{l}0.037 \\
(0.84)\end{array}$ & & $\begin{array}{l}0.006 \\
(0.14)\end{array}$ \\
\hline Volatility_B & & $\begin{array}{l}0.312 \\
(0.27)\end{array}$ & & $\begin{array}{c}-2.775 * * * \\
(-2.68)\end{array}$ & & $\begin{array}{l}-0.256 \\
(-0.18)\end{array}$ \\
\hline Illiquidity_B & & $\begin{array}{c}-0.875^{* * *} \\
(-3.41)\end{array}$ & & $\begin{array}{l}-0.298 \\
(-1.05)\end{array}$ & & $\begin{array}{c}-0.630 * \\
(-1.75)\end{array}$ \\
\hline Bond FE & Yes & Yes & Yes & Yes & Yes & Yes \\
\hline Month FE & Yes & Yes & Yes & Yes & Yes & Yes \\
\hline Adjusted $\mathrm{R}^{2}$ & 0.734 & 0.748 & 0.726 & 0.733 & 0.733 & 0.751 \\
\hline Observations & 16,639 & 16,112 & 11,259 & 10,987 & 21,766 & 21,735 \\
\hline
\end{tabular}




\section{Table 4. Timing of the Effect}

This table reports the regression of corporate bond spreads on three dummy variables: List $_{i t}(-6)$, List $_{i t}(6)$ and List $_{i t}\left(6^{+}\right)$, where List ${ }_{i t}(-6)$ is one if month $t$ is within six months before stock $i$ is added to the designated list and zero otherwise; $\operatorname{List}_{i t}(6)$ is one if month $t$ is within six months after stock $i$ is added to the designated list and zero otherwise; $\operatorname{List}_{i t}(7+)$ is one if month $t$ is seven or more months after stock $i$ is added to the designated list and zero otherwise. T-statistics, in parentheses, are based on standard errors clustered at the bond level are reported in parenthesis. *, **, and *** denote statistical significance at the $10 \%, 5 \%$, and $1 \%$ level, respectively.

\begin{tabular}{lcc}
\hline Dep.Var=Spread & $(1)$ & $(2)$ \\
\hline List $_{\text {it. }}(-6)$ & -0.043 & -0.030 \\
List $_{\text {it }}(6)$ & $(-0.70)$ & $(-0.51)$ \\
& $-0.142^{* *}$ & $-0.142^{* *}$ \\
List $_{\text {it }}(7+)$ & $(-2.15)$ & $(-2.27)$ \\
& $-0.333^{* * *}$ & $-0.334^{* * *}$ \\
(ln)Size & $(-3.68)$ & $(-3.86)$ \\
& & $-0.082^{*}$ \\
BM & & $(-1.77)$ \\
& & -0.028 \\
ROA & & $(-0.33)$ \\
& & $-0.057^{* * *}$ \\
Lev & & $(-7.25)$ \\
& & $0.668^{*}$ \\
SOE & & $(1.77)$ \\
& & $0.532^{* *}$ \\
Maturity & & $(2.51)$ \\
& & -0.164 \\
Volatility_B & & $(-1.19)$ \\
Illiquidity_B & & 0.219 \\
Bond Fixed Effects & Yes & $(0.19)$ \\
Month Fixed Effects & Yes & $-0.878^{* * *}$ \\
Adjusted ${ }^{2}$ & & $(-3.40)$ \\
Observations & & Yes \\
& & Yes \\
& & 0.749 \\
& & 16,112 \\
\hline & &
\end{tabular}




\section{Table 5. Placebo Tests}

This table reports the regression of corporate bond spreads on various dummy variables. List $_{i, t}$ is one if the issuer of bond $i$ is on the designated list in month $t$ and zero otherwise. List_Old $i t$ is one if stock $i$ is included in the designated list before the most recent addition and zero otherwise. List_Newit is one if stock $i$ is included in the designated list at the most recent addition and zero otherwise. For each of the five major additions to the designated list, we create a fictitious list of stocks that are ranked the highest according to (1) among the stocks that were not added to the list at the addition. We construct measure (1) based on the data during the three months before each addition event, and choose the number of the stocks on this fictitious list to be the same as the number of stocks that were actually added to the designated list at the most recent revision. This fictitious list stays the same until the next major revision. List_Placebo $o_{i t}$ is one if stock $i$ is on this fictitious list in month $t$, and zero otherwise. Control variables are the same as those in Table 3. T-statistics, in parentheses, are based on standard errors clustered at the bond level are reported in parenthesis. ${ }^{*}, * *$, and $* * *$ denote statistical significance at the $10 \%, 5 \%$, and $1 \%$ level, respectively.

Panel A. Full sample: 200901-201512

\begin{tabular}{lcccc}
\hline Dep.Var=Spread & $(1)$ & $(2)$ & $(3)$ & $(4)$ \\
\hline List & $-0.275^{* * *}$ & $-0.285^{* * *}$ & & \\
& $(-3.83)$ & $(-4.10)$ & & \\
List_Old & & & $-0.420^{* * *}$ & $-0.425^{* * *}$ \\
& & & $(-4.50)$ & $(-4.74)$ \\
List_New & & & $-0.215^{* * *}$ & $-0.220^{* * *}$ \\
& & & $(-3.40)$ & $(-3.64)$ \\
List_Placebo & -0.064 & -0.066 & -0.059 & -0.058 \\
& $(-1.07)$ & $(-1.17)$ & $(-1.01)$ & $(-1.05)$ \\
Controls & No & Yes & No & Yes \\
Bond Fixed Effects & Yes & Yes & Yes & Yes \\
Month Fixed Effects & Yes & Yes & Yes & Yes \\
Adjusted R2 & 0.734 & 0.748 & 0.736 & 0.750 \\
Observations & 16,640 & 16,112 & 16,640 & 16,112 \\
\hline
\end{tabular}


Panel B. Subsample: 201302-201512

\begin{tabular}{lcccc}
\hline Dep.Var=Spread & $(1)$ & $(2)$ & $(3)$ & $(4)$ \\
\hline List & $-0.327^{* * *}$ & $-0.339 * * *$ & & \\
List_Old & $(-3.14)$ & $(-3.43)$ & & \\
& & & $-0.378^{* * *}$ & $-0.387 * * *$ \\
List_New & & & $(-3.14)$ & $(-3.36)$ \\
& & & $-0.278^{* * *}$ & $-0.283^{* * *}$ \\
List_Placebo & -0.114 & -0.152 & -0.091 & -0.127 \\
& $(-1.22)$ & $(-1.63)$ & $(-0.95)$ & $(-1.32)$ \\
Controls & No & Yes & No & Yes \\
Bond Fixed Effects & Yes & Yes & Yes & Yes \\
Month Fixed Effects & Yes & Yes & Yes & Yes \\
Adjusted R2 & 0.765 & 0.771 & 0.765 & 0.771 \\
Observations & 12,131 & 11,673 & 12,131 & 11,673 \\
\hline
\end{tabular}


Table 6. Fuzzy RDD: Trading Restrictions and Corporate Bond Spreads

The first stage regression is based on the pooled data from addition 3 , 4, and 5 . For revision $k(k=3,4,5)$, and for each stock that is not on the designated list, we compute ranking $_{i}^{k}$ according to measure (1) based on the data during the three months before the revision date. The dummy variable $\tau_{i}^{k}$ is one if ranking $g_{i}^{k} \leq c^{k}$, and zero otherwise, where $c^{k}$ is the number of stocks that were added to the list at revision $k . D_{i}^{k}$ is a dummy variable that is one if stock $i$ is added to the designated list at revision $k$, and zero otherwise. Panel A reports the first-stage regression results for various bandwidths:

$$
D_{i}^{k}=\alpha_{0}+\alpha_{1} \tau_{i}^{k}+\alpha_{2}\left(\operatorname{ranking}_{i}^{k}-c^{k}\right)+\alpha_{3} \tau_{i}^{k} \times\left(\operatorname{ranking}_{i}^{k}-c^{k}\right)+\varepsilon_{i}^{k} .
$$

Panel B presents the second-stage regression:

$$
\operatorname{Spread}_{i t}=\beta_{0}+\beta_{1} \widehat{D}_{i}^{k}+\beta_{2}\left(\operatorname{ranking}_{i}^{k}-c^{k}\right)+\beta_{3} \tau_{i}^{k} \times\left(\operatorname{ranking}_{i}^{k}-c^{k}\right)+v_{i t},
$$

where $\widehat{D}_{i}^{k}$ is the fitted value from the first stage regression. T-statistics, in parentheses, are based on standard errors clustered at both the bond and month levels. *, **, and *** denote statistical significance at the $10 \%, 5 \%$, and $1 \%$ level, respectively.

Panel A: First Stage

\begin{tabular}{lcccccc}
\hline & \multicolumn{7}{c}{ Bandwidth } \\
\cline { 2 - 7 }$\tau$ & 100 & 90 & 80 & 70 & 60 & 50 \\
\cline { 2 - 7 } rank-c & 0.603 & 0.588 & 0.571 & 0.548 & 0.520 & 0.495 \\
& $(9.18)$ & $(8.87)$ & $(8.52)$ & $(8.25)$ & $(7.89)$ & $(6.96)$ \\
$\tau \times($ rank-c) & -0.003 & -0.003 & -0.004 & -0.004 & -0.006 & -0.007 \\
& $(-2.22)$ & $(-2.15)$ & $(-2.09)$ & $(-2.04)$ & $(-2.06)$ & $(-2.06)$ \\
Constant & 0.000 & 0.000 & 0.001 & 0.001 & 0.002 & 0.003 \\
& $(0.01)$ & $(0.11)$ & $(0.21)$ & $(0.25)$ & $(0.35)$ & $(0.55)$ \\
Adjusted $\mathrm{R}^{2}$ & 0.170 & 0.180 & 0.192 & 0.206 & 0.226 & 0.251 \\
Observations & $(2.39)$ & $(2.39)$ & $(2.38)$ & $(2.37)$ & $(2.37)$ & $(2.36)$ \\
\hline
\end{tabular}


Panel B: Second Stage

\begin{tabular}{lcccccc}
\hline & \multicolumn{7}{c}{ Bandwidth } \\
\cline { 2 - 7 }$\widehat{D}$ & 100 & 90 & 80 & 70 & 60 & 50 \\
\cline { 2 - 7 } & -0.303 & -0.307 & -0.309 & -0.271 & -0.204 & -0.250 \\
rank-c & $(-3.42)$ & $(-3.29)$ & $(-3.09)$ & $(-2.73)$ & $(-2.17)$ & $(-2.16)$ \\
& 0.001 & 0.001 & 0.001 & 0.002 & 0.002 & 0.000 \\
$\tau \times($ rank-c) & $(0.69)$ & $(0.59)$ & $(0.36)$ & $(0.58)$ & $(0.66)$ & $(0.03)$ \\
& -0.005 & -0.006 & -0.005 & -0.006 & -0.005 & -0.003 \\
Adjusted R ${ }^{2}$ & $(-6.07)$ & $(-4.79)$ & $(-3.52)$ & $(-2.83)$ & $(-1.74)$ & $(-0.68)$ \\
Observations & 0.461 & 0.465 & 0.466 & 0.468 & 0.469 & 0.466 \\
Controls & 2,236 & 1,968 & 1,779 & 1,559 & 1,368 & 1,111 \\
Time FE & Yes & Yes & Yes & Yes & Yes & Yes \\
\hline & Yes & Yes & Yes & Yes & Yes & Yes \\
\hline
\end{tabular}




\section{Table 7. Trading Restrictions and Stock Market}

This table reports the results from regressions of various stock market variables on List $_{i, t}$, which is one if stock $i$ is on the designated list in month $t$ and zero otherwise. Inefficiency is the price inefficiency measure from Hou and Moskowitz (2005). PIN is the probability of informed trading measure in Easley et al. (1996) and Easley, Hvidkjaer, and O'Hara (2010). PI is the price impact measure in Huang and Stoll (1996). BASpread B $_{i, t}$ is the average bid-ask spread of stock $i$ in month $t$, Amihud A $_{i, t}$ is the Amihud (2002) illiquidity ratio stock $i$ in month $t$, and Turnover $_{i, t}$ is the logarithm of the average turnover of stock $i$ in month $t$. T-statistics, in parentheses, are based on standard errors clustered at the bond level are reported in parenthesis. *, $* *$, and $* * *$ denote statistical significance at the $10 \%, 5 \%$, and $1 \%$ level, respectively.

Panel A

\begin{tabular}{lcccccc}
\hline & PriceEff & PI & PIN & BASpread & Amihud & Turnover \\
\hline List & $(1)$ & $(2)$ & $(3)$ & $(4)$ & $(5)$ & $(6)$ \\
\hline \multirow{2}{*}{ In)Size } & $-0.037^{* * *}$ & $-0.168^{* *}$ & $-0.005^{* *}$ & $-0.014^{* * *}$ & $-0.005^{* *}$ & $0.179 * * *$ \\
& $(-4.38)$ & $(-2.20)$ & $(-2.06)$ & $(-3.43)$ & $(-2.24)$ & $(4.78)$ \\
BM & $0.058^{* * *}$ & $-0.341^{* * *}$ & 0.001 & $-0.027^{* * *}$ & $-0.009^{* * *}$ & $-0.422^{* * *}$ \\
& $(6.27)$ & $(-4.74)$ & $(0.27)$ & $(-6.28)$ & $(-3.31)$ & $(-9.61)$ \\
ROA & -0.010 & $1.112^{* * *}$ & 0.007 & $0.070^{* * *}$ & $0.015^{* * *}$ & $-0.205^{* * *}$ \\
& $(-0.57)$ & $(7.72)$ & $(1.47)$ & $(9.09)$ & $(3.00)$ & $(-3.34)$ \\
Lev & $-0.005^{* * *}$ & 0.000 & 0.000 & $-0.002^{* * *}$ & -0.001 & 0.007 \\
& $(-3.66)$ & $(0.02)$ & $(0.03)$ & $(-4.74)$ & $(-1.48)$ & $(1.48)$ \\
SOE & 0.055 & 0.465 & $0.041^{* * *}$ & 0.018 & $0.037 * *$ & $-0.821^{* * *}$ \\
& $(0.93)$ & $(1.04)$ & $(3.26)$ & $(0.81)$ & $(2.45)$ & $(-4.51)$ \\
Volatility_S & -0.008 & 0.150 & -0.005 & 0.007 & 0.004 & 0.024 \\
& $(-0.36)$ & $(0.65)$ & $(-0.69)$ & $(0.70)$ & $(0.90)$ & $(0.43)$ \\
Illiquidity_S(t-1) & $0.469 * * *$ & $0.539 * * *$ & $-0.033^{* * *}$ & $-0.052^{* * *}$ & -0.018 & $2.670^{* * *}$ \\
& $(19.78)$ & $(4.13)$ & $(-5.01)$ & $(-9.87)$ & $(-1.32)$ & $(38.78)$ \\
Firm FE & 0.016 & -0.097 & 0.039 & $0.055^{* * *}$ & $0.092 * * *$ & $-0.665 * * *$ \\
Time FE & $(0.44)$ & $(-0.41)$ & $(1.54)$ & $(5.67)$ & $(3.90)$ & $(-5.12)$ \\
Adjusted R ${ }^{2}$ & Yes & Yes & Yes & Yes & Yes & Yes \\
Observations & Yes & Yes & Yes & Yes & Yes & Yes \\
\hline & 0.302 & 0.502 & 0.328 & 0.848 & 0.245 & 0.822 \\
& 13,159 & 13,186 & 4,859 & 13,188 & 13,209 & 13,209 \\
\hline
\end{tabular}


Panel B

\begin{tabular}{|c|c|c|c|c|c|c|}
\hline & PriceEff & $P I$ & $P I N$ & BASpread & Amihud & Turnover \\
\hline & $(1)$ & $(2)$ & (3) & (4) & (5) & $(6)$ \\
\hline \multirow[t]{2}{*}{$\operatorname{List}(-6,0)$} & -0.001 & 0.010 & -0.004 & -0.000 & $-0.010 * * *$ & $0.209 * * *$ \\
\hline & $(-0.06)$ & $(0.13)$ & $(-1.32)$ & $(-0.08)$ & $(-4.03)$ & $(4.40)$ \\
\hline \multirow[t]{2}{*}{ List $[0,6]$} & $-0.029 * * *$ & $-0.120 *$ & $-0.009 * * *$ & $-0.013 * *$ & $-0.010 * * *$ & $0.281^{* * *}$ \\
\hline & $(-2.66)$ & $(-1.66)$ & $(-2.98)$ & $(-2.32)$ & $(-4.44)$ & (5.84) \\
\hline \multirow[t]{2}{*}{ List $[7,+)$} & $-0.037 * * *$ & $-0.152 *$ & $-0.006^{* *}$ & $-0.015 * * *$ & $-0.006^{* *}$ & $0.240 * * *$ \\
\hline & $(-3.26)$ & $(-1.74)$ & $(-2.03)$ & $(-2.78)$ & $(-2.29)$ & (4.94) \\
\hline \multirow[t]{2}{*}{ (In)Size } & $0.058 * * *$ & $-0.316 * * *$ & 0.001 & $-0.027 * * *$ & $-0.009 * * *$ & $-0.433 * * *$ \\
\hline & (6.27) & $(-5.15)$ & (0.39) & $(-6.27)$ & $(-3.11)$ & $(-9.81)$ \\
\hline \multirow[t]{2}{*}{$B M$} & -0.010 & $0.998 * * *$ & 0.007 & $0.069 * * *$ & $0.014 * * *$ & $-0.189 * * *$ \\
\hline & $(-0.58)$ & (8.10) & $(1.42)$ & (9.19) & (2.86) & $(-3.09)$ \\
\hline \multirow[t]{2}{*}{$R O A$} & $-0.005 * * *$ & 0.004 & -0.000 & $-0.002 * * *$ & -0.001 & 0.007 \\
\hline & $(-3.64)$ & $(0.46)$ & $(-0.02)$ & $(-4.71)$ & $(-1.52)$ & (1.50) \\
\hline \multirow[t]{2}{*}{ Lev } & 0.055 & 0.442 & $0.040 * * *$ & 0.018 & $0.036 * *$ & $-0.808 * * *$ \\
\hline & $(0.94)$ & $(1.27)$ & (3.22) & $(0.81)$ & (2.38) & $(-4.32)$ \\
\hline \multirow[t]{2}{*}{ SOE } & -0.009 & 0.015 & -0.004 & 0.007 & 0.004 & 0.008 \\
\hline & $(-0.39)$ & $(0.09)$ & $(-0.62)$ & $(0.68)$ & (1.08) & $(0.13)$ \\
\hline \multirow[t]{2}{*}{ Volatility_S } & $0.469 * * *$ & $0.449 * * *$ & $-0.032 * * *$ & $-0.052 * * *$ & -0.017 & $2.657 * * *$ \\
\hline & (19.74) & (4.39) & $(-4.89)$ & $(-9.88)$ & $(-1.26)$ & (38.89) \\
\hline \multirow[t]{2}{*}{ Illiquidity_S(t-1) } & 0.016 & -0.187 & 0.036 & $0.055^{* * *}$ & $0.091 * * *$ & $-0.645 * * *$ \\
\hline & $(0.45)$ & $(-1.00)$ & (1.43) & $(5.66)$ & (3.86) & $(-5.02)$ \\
\hline Firm FE & Yes & Yes & Yes & Yes & Yes & Yes \\
\hline Time FE & Yes & Yes & Yes & Yes & Yes & Yes \\
\hline Adjusted $\mathrm{R}^{2}$ & 0.328 & 0.533 & 0.329 & 0.854 & 0.274 & 0.830 \\
\hline Observations & 13,159 & 13,186 & 4,859 & 13,188 & 13,209 & 13,209 \\
\hline
\end{tabular}




\section{Table 8. Opaqueness and the Effect of Trading Restrictions}

This table presents the regression of corporate bond spreads on List and its interaction with measures of the opaqueness of the firm, including Intangibility_High, NoDualList, NoBig4Audit, ForecastErr_High, and ForecastDisp_High. List is one if the stock that issues the bond is on the designated list and zero otherwise. Intangibility_High is a dummy variable that equals one if the intangibility of the stock is above the median of the sample and zero otherwise. NoDualList is a dummy variable that equals one if a stock does not have dual listed shares (B or $\mathrm{H}$ shares) and zero otherwise. NoBig4Audit is a dummy variable that equals one if the firm is not audited by a big 4 auditor and zero otherwise. ForecastErr_High is a dummy variable that equals one if the firm's analyst forecast error is higher than the median of the full sample and zero otherwise. ForecastDisp_High is a dummy variable that equals one if the firm's analyst forecast dispersion is higher than the median of the full sample and zero otherwise. T-statistics, in parentheses, are based on standard errors clustered at the bond level are reported in parenthesis. *, **, and *** denote statistical significance at the $10 \%, 5 \%$, and $1 \%$ level, respectively.

\begin{tabular}{lccccc}
\hline & $(1)$ & $(2)$ & $(3)$ & $(4)$ & $(5)$ \\
Dep.Var=Spread & Intangibility & DualList & Audit & Error & Dispersion \\
\hline List & $-0.179^{* * *}$ & 0.018 & -0.058 & $-0.143^{* * *}$ & $-0.137^{* * *}$ \\
& $(-3.01)$ & $(0.18)$ & $(-0.63)$ & $(-2.87)$ & $(-2.67)$ \\
List×Opaque & $-0.135^{* *}$ & $-0.294^{* * *}$ & $-0.238^{* *}$ & $-0.140^{* *}$ & $-0.142^{* * *}$ \\
& $(-2.00)$ & $(-2.86)$ & $(-2.37)$ & $(-2.44)$ & $(-2.63)$ \\
Opaque & $0.115^{*}$ & $0.296^{*}$ & $0.380^{* *}$ & 0.016 & $0.074^{*}$ \\
& $(1.84)$ & $(1.70)$ & $(2.09)$ & $(0.35)$ & $(1.79)$ \\
Other Controls & Yes & Yes & Yes & Yes & Yes \\
Bond Fixed Effects & Yes & Yes & Yes & Yes & Yes \\
Month Fixed Effects & Yes & Yes & Yes & Yes & Yes \\
Adjusted R & 0.749 & 0.749 & 0.749 & 0.741 & 0.740 \\
Observations & 16,112 & 16,112 & 16,112 & 14,488 & 13,849 \\
\hline
\end{tabular}




\section{Table 9. Credit Ratings and the Effect of Trading Restrictions}

This table reports the regression of corporate bond spreads on List and its interaction with bond credit ratings. List is one if the stock that issues the bond is on the designated list and zero otherwise. $A A A$ is one if a bond is rated as AAA and zero otherwise. $A A+$ is one if a bond is rated as $\mathrm{AA}+$ and zero otherwise. AAorBelow is one if a bond is rated as AA or below and zero otherwise. All other control variables are defined in Appendix A. T-statistics, in parentheses, are based on standard errors clustered at the bond level are reported in parenthesis. *, **, and *** denote statistical significance at the $10 \%, 5 \%$, and $1 \%$ level, respectively.

\begin{tabular}{|c|c|c|}
\hline Dep.Var=Spread & $(1)$ & (2) \\
\hline \multirow[t]{2}{*}{ List*AAA } & $-0.128 * *$ & -0.065 \\
\hline & $(-1.96)$ & $(-1.02)$ \\
\hline \multirow[t]{2}{*}{ List*AA+ $^{*}$} & $-0.234 * * *$ & $-0.257 * * *$ \\
\hline & $(-3.21)$ & $(-3.63)$ \\
\hline \multirow[t]{2}{*}{ List*AAorBelow } & $-0.295 * * *$ & $-0.336 * * *$ \\
\hline & $(-3.60)$ & $(-4.36)$ \\
\hline \multirow[t]{2}{*}{$A A A$} & $-1.123 * * *$ & $-0.993 * * *$ \\
\hline & $(-2.84)$ & $(-2.68)$ \\
\hline \multirow[t]{2}{*}{$A A^{+}$} & -0.338 & -0.253 \\
\hline & $(-1.07)$ & $(-0.91)$ \\
\hline \multirow[t]{2}{*}{ (In)Size } & & -0.074 \\
\hline & & $(-1.64)$ \\
\hline \multirow[t]{2}{*}{$B M$} & & -0.023 \\
\hline & & $(-0.27)$ \\
\hline \multirow[t]{2}{*}{$R O A$} & & $-0.059 * * *$ \\
\hline & & $(-7.76)$ \\
\hline \multirow[t]{2}{*}{ Lev } & & $0.672 *$ \\
\hline & & $(1.79)$ \\
\hline \multirow[t]{2}{*}{ SOE } & & $0.501 * *$ \\
\hline & & $(2.42)$ \\
\hline \multirow[t]{2}{*}{ Maturity } & & -0.159 \\
\hline & & $(-1.11)$ \\
\hline \multirow[t]{2}{*}{ Volatility_B } & & 0.426 \\
\hline & & $(0.38)$ \\
\hline \multirow[t]{2}{*}{ Illiquidity_B } & & $-0.824 * * *$ \\
\hline & & $(-3.28)$ \\
\hline Bond Fixed Effects & Yes & Yes \\
\hline Month Fixed Effects & Yes & Yes \\
\hline Adjusted R2 & 0.735 & 0.749 \\
\hline Observations & 16,639 & 16,112 \\
\hline
\end{tabular}


Table 10. Corporate Governance and the Effect of Trading Restrictions

This table present $\mathrm{s}$ the regression of corporate governance measures on List, which is one if the stock is on the designated list and zero otherwise. We adopt four commonly used corporate governance measures, including the ratio of independent directors (IndepDir), CEO duality (Dual), divergence ratio (Divergence), and managerial ownership (MgtHold). All other control variables are defined in Appendix A. T-statistics, in parentheses, are based on standard errors clustered at the bond level are reported in parenthesis. *, **, and *** denote statistical significance at the $10 \%, 5 \%$, and $1 \%$ level, respectively.

\begin{tabular}{lcccc}
\hline & IndepDir & Dual & Divergent & MgtHold \\
\cline { 2 - 5 } List & $(1)$ & $(2)$ & $(3)$ & $(4)$ \\
\cline { 2 - 5 } In)Size & -0.000 & 0.000 & 0.634 & 0.015 \\
& $(-0.11)$ & $(0.11)$ & $(1.27)$ & $(0.69)$ \\
BM & 0.000 & -0.002 & -0.543 & -0.000 \\
& $(0.15)$ & $(-1.28)$ & $(-1.31)$ & $(-0.01)$ \\
ROA & 0.006 & $0.005 *$ & -0.815 & 0.003 \\
& $(0.92)$ & $(1.80)$ & $(-0.83)$ & $(0.07)$ \\
Lev & 0.000 & 0.001 & 0.129 & 0.001 \\
& $(0.18)$ & $(1.14)$ & $(1.06)$ & $(0.18)$ \\
SOE & -0.017 & -0.024 & 1.759 & 0.222 \\
& $(-0.62)$ & $(-0.79)$ & $(0.49)$ & $(1.34)$ \\
Illiquidity_S & -0.022 & -0.016 & 0.990 & -0.119 \\
\multirow{2}{*}{ Vol_S } & $(-1.02)$ & $(-1.04)$ & $(0.24)$ & $(-0.93)$ \\
& 0.010 & -0.001 & 1.149 & -0.084 \\
Firm Fixed Effects & $(0.39)$ & $(-0.03)$ & $(0.36)$ & $(-0.41)$ \\
Year Fixed Effects & -0.009 & -0.001 & 2.091 & 0.080 \\
Adjusted R2 & $(-0.82)$ & $(-0.21)$ & $(0.93)$ & $(0.77)$ \\
Observations & Yes & Yes & Yes & Yes \\
\hline
\end{tabular}




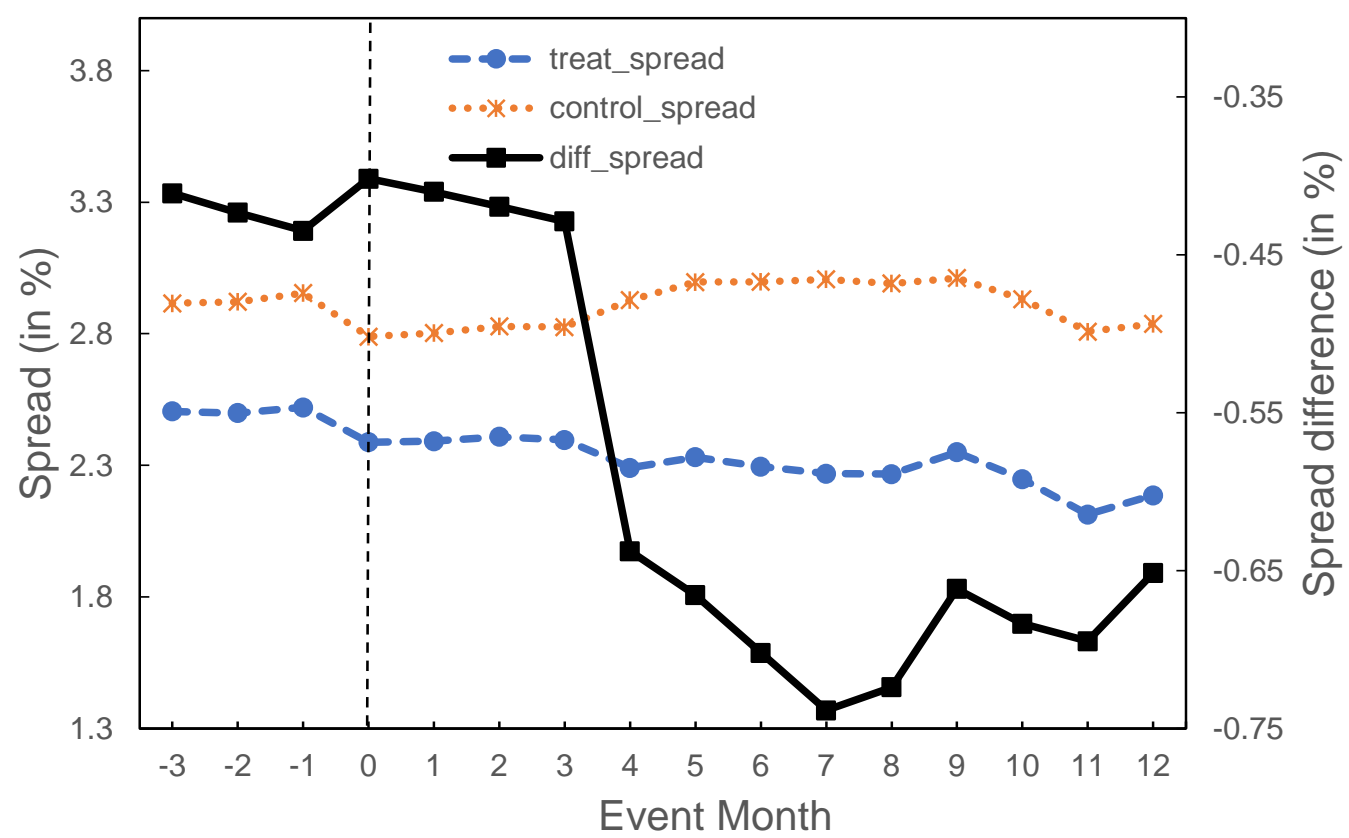

Figure 1. Bond Spreads Around Additions of Margin Trading List

This figure plots the average bond spreads of treated (dashed line) and control firms (dotted line) for each month (from -3 to +12 month) around the event month that stocks are added to the designated list. The solid line represents the difference in the average bond spreads between treated and control firms. Treated firms refer to firms that are included in the margin trading list and controls firms refer to firms that are not included in the list. 
Figure 2. The probability of addition to the margin trading list and stock ranks

The probability of addition to the designated list is plotted against stock ranks for addition 3 (Panel A), 4 (Panel B), and 5(Panel C). Bin width equals 10. The y-axis represents the average probability over the number of ranks equal to the bin width. The $\mathrm{x}$-axis equals (rank - cutoff)/bin width.
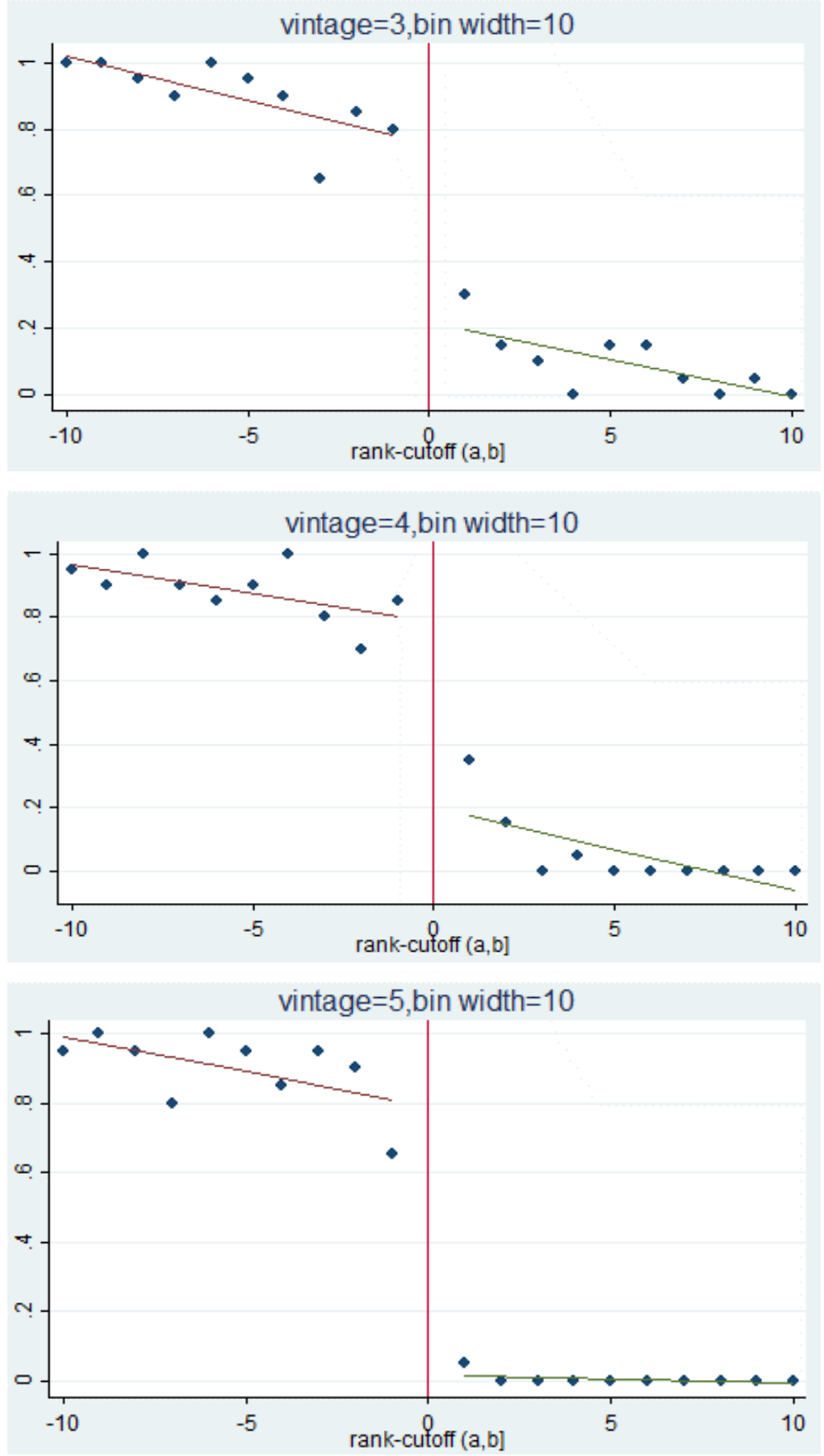